Board of Governors of the Federal Reserve System

International Finance Discussion Papers

Number 691

December 2000

\title{
INFORMATION COSTS AND HOME BIAS: AN ANALYSIS OF U.S. HOLDINGS OF FOREIGN EQUITIES
}

Alan G. Ahearne, William L. Griever, and Francis E. Warnock

NOTE: International Finance Discussion Papers are preliminary materials circulated to stimulate discussion and critical comment. References in publications to International Finance Discussion Papers (other than an acknowledgment that the writer has had access to unpublished material) should be cleared with the author or authors. Recent IFDPs are available on the Web at www.federalreserve.gov/pubs/ifdp/. 
INFORMATION COSTS AND HOME BIAS:

AN ANALYSIS OF U.S. HOLDINGS OF FOREIGN EQUITIES

Alan G. Ahearne, William L. Griever, and Francis E. Warnock ${ }^{\star}$

\begin{abstract}
We aim to provide insight into the observed equity home bias phenomenon by analyzing the determinants of U.S. holdings of equities across a wide range of countries. In particular, we explore the role of information costs in determining the country distribution of U.S. investors' equity holdings using a comprehensive new data set on U.S. ownership of foreign stocks. We find that U.S. holdings of a country's equities are positively related to the share of that country's stock market that is listed on U.S. exchanges, even after controlling for capital controls, trade links, transaction costs, and historical risk-adjusted returns. We attribute this finding to the fact that foreign firms that list on U.S. exchanges are obliged to provide standardized, credible financial information, thereby reducing information costs incurred by U.S. investors. This obligation stems from U.S. investor protection regulations, which include stringent disclosure requirements, reconciliation of financial statements to U.S. standards, and an investor-friendly regulatory environment. Our results support the hypothesis that information costs are an important source of home bias: Foreign countries whose firms do not alleviate information costs by listing on a U.S. exchange are more severely underweighted in U.S. equity portfolios.
\end{abstract}

JEL Classification: G11, G15, M40, K00

Keywords: information asymmetries, investor protection, accounting standards, portfolio choice

* The authors thank Stanley Black, Rob Dekle, Andrew Karolyi, Philip Lane, Tim McCormick, Darius Miller, Assaf Razin, Helene Rey, Sergei Sarkissian, participants at seminars at the IF Monday Workshop and the IMF Institute, and participants at the Washington Area Finance Association, Southern Economic Association, and Western Economic Association conferences for helpful comments and discussions; Jean Tobin of the NYSE for providing information on non-U.S. NYSE-listed firms; Eric Richards for help with the CompuStat database; and Nancy Baer, Chad Cleaver, Molly Mason, and Yvonne Nickens for research assistance. All errors are our own. The views in this paper are solely the responsibility of the authors and should not be interpreted as reflecting the views of the Board of Governors of the Federal Reserve System, or of any other person associated with the Federal Reserve System. Corresponding author: frank.warnock@,frb.gov 


\section{Introduction}

The international version of the classical capital asset pricing model (ICAPM), based on traditional portfolio theory developed by Sharpe (1964) and Linter (1965), predicts that to maximize risk-adjusted returns investors should hold the world market portfolio of risky assets, irrespective of their country of residence. In practice, however, the proportion of foreign assets in investors' portfolios tends to be very small. In the case of equities, foreign stocks make up a disproportionately small share of investors' equity holdings when one considers relative stock market capitalizations. Equivalently, there is evidence of large gains from international portfolio diversification; see, for example, Lewis (1999). The phenomenon whereby individuals hold too little of their wealth in foreign assets relative to the predictions of theory, commonly referred to as the home bias puzzle, is discussed by among others French and Poterba (1991), Cooper and Kaplanis (1994), and Tesar and Werner (1995).

Figure 1 shows the share of foreign stocks in the equity portfolio of U.S. investors, compiled using data from U.S. Flow of Funds statistics. ${ }^{1}$ The figure indicates that although the degree of home bias in U.S. equity portfolios lessened between the mid-1980s and the mid1990s, it remained relatively large. As of end-1997, foreign equities comprised roughly 10 percent of U.S. equity holdings, a greater share than the estimated 2 percent in the late 1980s, but far short of the 52 percent of world stock market capitalization accounted for by foreign stocks. $^{2}$

The ICAPM prediction that individuals hold equities from around the world in proportion to market capitalizations is based on the assumption that there are no barriers to international investment. In practice, such barriers do exist, although many have fallen substantially over the past few decades. Direct barriers--such as capital controls, foreign taxes, and transactions costs--

${ }^{1}$ In Figure 1, the two data points marked with asterisks, March 1994 and December 1997, are the only dates for which actual data on U.S. holdings of foreign equities exist; for all other periods, the Bureau of Economic Analysis (BEA) estimates holdings based on flows and valuation adjustments.

${ }^{2}$ The interested reader will note from Figure 1 that the share of foreign equities in U.S. portfolios rose sharply between 1987 and 1994. Between 1987 and 1990, the increase was due to sluggish growth in U.S. stock markets; between 1992 and 1994, strong increases in U.S. holdings of foreign equities outpaced increases in U.S. market capitalization. Since 1994, U.S. investors have continued to add foreign stocks to their portfolios, but the share of foreign stocks has leveled off, reflecting gains in U.S. stock prices. 
have been lowered significantly, and in some cases completely eliminated. That the foreign equity share of U.S. investors' portfolios is still so low has led researchers to search for other possible causes of home bias. In particular, researchers have increasingly focused on the potential role of indirect barriers.

One type of indirect barrier that has received considerable attention recently is information costs. A number of recent empirical studies provide evidence that information costs affect the composition of investors' portfolios. For example, there is evidence that foreign equity portfolios are skewed towards the equities of large firms, for which more information is readily available; see Kang and Stulz (1997) for evidence on foreign investment in Japanese securities and Treasury Department (1998) for evidence on foreign investment in U.S. securities. Portes and Rey (1999) provide evidence that information flows are an important determinant of crossborder equity transactions. Even within countries, there is evidence that investors tend to hold stocks of local companies, about which they presumably have more information. For example, Coval and Moskowitz (1999) show that U.S. investment managers exhibit a strong preference for locally-headquartered firms. Each of these studies suggests that asymmetric information between local and non-local investors may be an important factor for investment decisions.

In this paper, we provide additional evidence that information asymmetries are an important determinant of the observed home bias of U.S. investors. In particular, we explore the role of information asymmetries that arise from differences in accounting standards, disclosure requirements, and regulatory environments across countries. When investors contemplate purchasing equity in a foreign company, they must glean from published accounts information that is based on accounting principles and disclosure requirements that may differ greatly from those in their home country. Moreover, the credibility of this information is determined to a large extent by the regulatory environment, which also varies considerably from country to country. ${ }^{3}$ Cross-country differences in accounting principles, disclosure requirements, and

${ }^{3}$ Bordo, Eichengreen, and Irwin (1999) note that the U.S. railroad industry received a disproportionately large share of portfolio investment flows from Britain in the late $19^{\text {th }}$ century. They argue that this was because information about the railroad sector was more readily available and of better quality, due in large part to standardized accounting principles, disclosure requirements of the New York Stock Exchange (NYSE), and regulation by the Interstate 
regulatory environments--which together can be thought of as investor protection regulations-give rise to information costs that must be borne by foreign investors. Information costs associated with investing in some countries may be significantly higher than in others.

Some foreign firms effectively alleviate information costs facing U.S. investors by listing their stocks on U.S. exchanges, either directly or as Level 2 or Level 3 American Depositary Receipts (ADRs). To list on U.S. exchanges, the foreign firm must reconcile its accounts with U.S. generally accepted accounting principles (GAAP), meet the SEC's stringent disclosure requirements, and subject itself to the associated regulatory burden, tasks that are by no means costless to the firm. ${ }^{4}$

We are not the first to suggest that cross-listing can alleviate information asymmetries. For example, Lins, Strickland, and Zenner (2000) argue that firms from developing countries that list on U.S. exchanges gain enhanced access to capital markets due to a reduction in information asymmetries that reflects greater disclosure requirements, shareholder rights protection, liquidity, and analyst following. Similarly, Baker, Nofsinger, and Weaver (2000) find a cross-listing on the NYSE is associated with increased analyst coverage and decreased cost of capital, and that these benefits are greater than for foreign firms that list on the London Stock Exchange, partially offsetting the higher costs associated with a NYSE listing. Stulz (1999) argues that firms from countries with lower disclosure requirements cannot credibly communicate their prospects to investors. To raise external funds, such firms might cross-list on an exchange with higher disclosure standards, thereby sending a positive signal to investors. A similar rationale for crosslisting on a market with greater regulatory strictness appears in Fuerst (1998). Finally, La Porta, Lopez-de-Silanes, and Shleifer (1999) analyze ownership concentration in 27 wealthy economies and find that firms from countries with poor shareholder protection are less widely held. They

Commerce Commission, a precursor to the Securities and Exchange Commission (SEC).

${ }^{4}$ We are not suggesting that Level 1 ADRs reduce information costs to U.S. investors. Level 1 ADRs trade on the OTC market as pink sheets, are relatively illiquid, and are not subject to the stringent regulatory requirements. In number, the vast majority of ADR programs are Level 1; by market capitalization, exchange-listed (Levels 2 and 3) ADRs are much greater. See Karolyi (1998) and Miller (1999) for excellent discussions of ADR programs. 
conclude that these firms can improve their access to external capital by listing on a U.S. exchange.

Our work also focuses on the role of listing on U.S. exchanges in reducing information asymmetries, but from the perspective of investors. We argue that firms that do not reduce information costs to U.S. investors by listing on U.S. exchanges are more likely to be underweighted in U.S. portfolios. By extension, countries whose firms tend not to list on U.S. exchanges will be more severely underweighted in U.S. portfolios, resulting in home bias at an aggregate level.

To explore the implications of information costs for the home bias puzzle, we use a comprehensive new data set on U.S. investors' holdings of foreign equities, covering 164 countries, of which we include the largest 48 in our statistical analysis. We find that the share of a country's stock market that is listed on U.S. exchanges--and hence the share of that country's firms that have alleviated information costs associated with differences in financial standards, requirements, and regulations--helps explain the country-distribution of U.S. investors' equity portfolio, even after controlling for other variables such as trade flows, foreign ownership restrictions, transaction costs, and reward-to-risk ratios.

The remainder of the paper is organized as follows. Section 2 presents an illustrative model and discusses in more detail sources of information asymmetries, focusing on differences in accounting standards across countries. Section 3 describes our data set on U.S. investors' holdings of foreign equities. The main results of statistical analysis on U.S. investors' holdings

of foreign equities are presented in Section 4. Section 5 presents further regression results and Section 6 concludes.

\section{Role of Asymmetric Information Information Costs and Home Bias: A Model}

It is well known that there are costs associated with investing abroad. Some of these costs are explicit, such as transaction fees, taxes, commissions, and the costs of gathering information. In addition, investors face implicit costs, including costs that arise from informational disadvantages vis-a-vis local residents. Both types of costs serve to lower 
expected net returns on foreign investment. For example, investors who are considering which stocks to purchase in a particular foreign country will want to differentiate between firms in that country with good profit prospects and those whose prospects are poor. To the extent that lax disclosure requirements--or lax enforcement of disclosure requirements--makes such differentiation difficult, these investors may end up holding more foreign "lemons" than local insiders who have better information.

To fix ideas, we present a model of international portfolio allocation drawn from Cooper and Kaplanis (1986). The model includes country-specific proportional investment costs, representing both explicit and implicit costs of investing abroad. ${ }^{5}$ Proportional costs are a valid representation of the information costs we envision because it is not sufficient to merely learn the accounting standards of the foreign country (which would be a fixed cost). Given differences in disclosure requirements and regulatory environments, in many countries the true picture of earnings is available only to insiders. While one could argue that the cost of becoming an insider is fixed at the firm level, the number of firms is not fixed, so the cost could still be represented by a proportional cost at the country level. ${ }^{6}$

Under standard ICAPM assumptions, the $i$ th investor's optimization problem is to choose $x_{i}$, the allocation of her wealth among risky securities in $n$ countries, to maximize expected returns net of costs, or:

$$
\max \left(x_{i}^{\prime} R-x_{i}^{\prime} c_{i}\right)
$$

subject to

$$
x_{i}^{\prime} V x_{i}=v
$$

${ }^{5}$ Seminal papers modeling the effects of barriers to international investment are Black (1974) and Stulz (1981).

${ }^{6}$ Many researchers note that proportional costs are not likely to inhibit cross-border investment because Tesar and Werner (1995) showed that the turnover rates on foreign portfolios are quite high. However, using holdings data from U.S. benchmark surveys, Warnock (2000) shows that this result was based on published, official holdings estimates that grossly underestimated cross-border holdings. 


$$
x_{i}^{\prime} I=1
$$

where

$$
\begin{array}{ll}
x_{i} & \text { is a column vector, the } n \text {th element of which, } x_{i n} \text {, is the proportion of } \\
& \text { individual } i \text { 's wealth invested in securities in country } n \\
& \text { is a column vector of pre-cost expected returns } \\
c_{i} & \text { is a column vector, the } n \text {th element of which, } c_{i n}, \text { is the cost to investor } i \text { of } \\
& \text { holding securities in country } n \\
v & \text { is a constant } \\
V & \text { is the variance/covariance matrix of the gross (pre-cost) returns of the } \\
& \text { securities } \\
I & \text { is a unity column vector } \\
W_{i} & \text { is the proportion of world wealth owned by country } i \\
M & \text { is a column vector, the } i \text { th element of which, } M_{i}, \text { is the proportion of world }
\end{array}
$$

For simplicity, assume that the covariance matrix, $V$, is diagonal with all variances equal to $\mathrm{s}^{2}$. Imposing the world capital market clearing condition, $\sum W_{i} x_{i}=M$, the solution to this problem simplifies to ${ }^{7}$

$$
h s^{2}\left(x_{i n}-M_{n}\right)=-c_{i n}+b_{n}+a_{i}-d
$$

where

$$
\begin{aligned}
& a_{i}=z^{\prime} c_{i} \quad \text { (weighted average marginal cost for investor } i \text { ) } \\
& b_{n}=\sum M_{j} c_{j n} \quad \text { (world weighted average cost in country } n \text { ) } \\
& d=z^{\prime} \sum M_{i} c_{i} \quad \text { (world weighted average cost) }
\end{aligned}
$$

and

$z=V^{-1} I /\left(I^{\prime} V^{-1} I\right)$ (global minimum variance portfolio)

\footnotetext{
${ }^{7}$ Here, $h$ is the Lagrange multiplier on the constraint $x_{i}^{\prime} V x_{i}=v$.
} 
In the case with no costs to investing, $c_{i}$ is a zero vector and the right-hand side of (1) is zero. Hence $x_{i n}=M_{n}$; that is, investor $i$ allocates his wealth across countries according to market capitalizations.

In the more general case with non-zero and non-uniform costs, if the actual cost to investor $i$ of investing in country $n\left(c_{i n}\right)$ is high relative to investor $i$ 's average cost to investing $\left(a_{i}\right)$ or relative to all investors' costs to investing in country $n\left(b_{n}\right)$, then the right-hand side of (1) is likely negative and investor $i$ will underweight country $n$ in his portfolio. The higher are costs in a particular foreign market, the more severely underweighted that country will be in the investor's portfolios. Moreover, since investors do not face such costs in their home market, equation (1) predicts an overweighting of domestic stocks--the equity home bias--when costs exist in other countries.

\section{Listing on a U.S. Exchange: Reducing the Information Costs for U.S. Investors ${ }^{8}$}

The model in the preceding section shows that investment costs, including implicit costs arising from information asymmetries, can result in some countries being underweight in investors' portfolios. One implication is that investors are likely to underweight countries for which it is costly to gather and analyze firm-level information.

In this section we discuss in greater detail one particular source of information about a firm's financial condition and prospects: published financial statements. As mentioned earlier, accounting practices differ greatly around the world. In some countries, accounting practices are thought to favor company insiders over investors, while, in other countries, especially the United States, accounting rules are geared towards investor protection. To list on a U.S. exchange, the SEC requires non-U.S. firms to make full disclosure and provide a reconciliation of foreign financial statements to U.S. GAAP. This allows investors to compare companies more easily across industries, irrespective of geography; without this requirement U.S. investors would be confronted with financial statements prepared under at least 40 different sets of accounting principles. Reconciliation of foreign financial statements to U.S. GAAP imposes a significant

\section{(1994).}

${ }^{8}$ The discussion of accounting practices in this section borrows heavily from Breeden 
burden on the foreign company, and at the same time represents a saving for U.S. investors, whose cost of acquiring information about the company is greatly reduced.

Perhaps more important than reconciliation to U.S. GAAP are the SEC's stringent disclosure requirements. U.S. investors benefit when foreign firms list on U.S. exchanges because problems associated with lax disclosure requirements--or lax enforcement of disclosure requirements--that often cloud the true picture of a firm's financial condition are alleviated. The case of Daimler Benz's listing on the NYSE in 1993 is illustrative. Accounting rules in Germany give companies wide latitude in how they choose to portray current earnings or financial conditions. In particular, under German GAAP the firm can, with few restrictions, substantially understate or overstate earnings by creating hidden reserves, or provisions. In good times, reported income can be reduced by creating provisions for potential future adverse events. ${ }^{9}$ In bad times, the company can release reserves into current income in a way that masks current losses.

To list on the NYSE, Daimler-Benz had to reconcile its financial statements going back three years. In doing so, the DM200 million profit for the first half of 1993 it had reported under German GAAP became a DM1 billion loss under U.S. GAAP. The difference was an undisclosed release of DM1.5 billion in provisions into income, clearly shown in Daimler's reconciliation to U.S. GAAP. Under German GAAP, only insiders such as the firm's board members--which typically include managers from German banks--knew its true financial condition without the smoothing out by provisions.

Our hypothesis in this paper is that foreign firms that list on U.S. exchanges, and thereby reduce information costs for U.S. investors, are more likely to be held by U.S. investors. At the country level, we expect the extent to which a country's firms list in the U.S. to be an important determinant of its share in the U.S. foreign equity portfolio. ${ }^{10}$

\footnotetext{
${ }^{9}$ Under U.S. GAAP the event must be probable and estimable before a reserve may be booked.

${ }^{10}$ Listing in the U.S. also reduces transactions costs faced by U.S. investors. We discuss this further in Section V.
} 


\section{Data ${ }^{11}$}

In the past, the approach taken by researchers (and by the U.S. government) to estimating U.S. portfolio investment in foreign equity securities involved making a guess of the initial stock, which was then updated using subsequent flow data, perhaps price-adjusting along the way; see for example French and Poterba (1991), Tesar and Werner (1995), Cooper and Kaplanis (1994).

Warnock and Mason (2000) show, however, that estimates of country-level holdings using flow data can be wildly off the mark, likely due to some combination of inadequacies in the flow data and inappropriate valuation adjustments. Country-level valuation adjustments can be incorrect if calculated using a market index when U.S. investors hold a portfolio that differs significantly from the market. The flow data can be incorrect because, for the United States, data on transactions in foreign equities are collected based on the country of the transactor, not the country of the security. When the country of the transactor differs from the country of the security--as is often the case with trades through financial centers such as the United Kingdom and Hong Kong--the country distribution is distorted in the transactions data.

Our data set is subject to neither of these problems. We use data drawn from the U.S. Treasury Department's comprehensive surveys of U.S. holdings of foreign securities, conducted as of March 31, 1994 and December 31, 1997. ${ }^{12}$ The surveys collected detailed information at the individual security level for U.S.-held foreign equities; the country attribution of each security was determined using both commercial and respondent data. Reporting to the survey was mandatory, with penalties for noncompliance, and the data received were subjected to extensive analysis and editing before they were accepted as accurate. The reporters consisted mainly of large custodians and large institutional investors, both of which were universally included in the sample. ${ }^{13}$ Holdings of U.S. private investors were included inasmuch as they were through U.S. mutual funds or are entrusted to U.S.-resident custodians for safekeeping.

${ }^{11}$ Details on data and sources are also provided in the Data Appendix.

${ }^{12}$ The only other such survey was conducted in 1943.

${ }^{13}$ Smaller custodians and institutional investors were sampled, but 99 percent of the data was from the major reporters. 
Further details of the 1997 survey, including findings and methodology, are discussed in Treasury Department and Federal Reserve Board (2000).

Table 1 presents our data on the share of U.S. holdings of equities by country as of end1997. Column 1 of the table shows the strong preference by U.S. investors for domestic equities over foreign equities -- almost 90 percent of the U.S. equity portfolio consists of U.S. stocks. For foreign equities, the United Kingdom was the country of choice for U.S. investors, with U.K. stocks comprising almost 2 percent of the U.S. equity portfolio, followed by Japan, the Netherlands, France and Canada. U.S. holdings of foreign equities are quite concentrated, with the top 15 countries accounting for almost four-fifths of total U.S. holdings of foreign equities.

Table 1 (column 2) also presents what we refer to as benchmark shares--hypothetical shares of U.S. equity holdings against which we can compare the actual holdings. By construction, these benchmarks are simply the weights of each country's stock market capitalization in world stock market capitalization at end-1997. Moreover, these benchmarks are exactly the shares predicted by the ICAPM model in Section II. That is, these benchmarks are the shares of U.S. equity holdings by country in a hypothetical world in which global capital markets were complete and investors in all countries had identical preferences and chose portfolios optimally based on standard portfolio theory. For example, given the size of U.S. stock markets at end-1997, the model in Section 2 predicts that domestic equities should have made up just less than half of U.S. investors' equity portfolios.

Comparing actual holdings to the benchmark shares gives an indication of the degree to which U.S. investors underweight different foreign countries. As expected, for all countries other than the United States, U.S. holdings are less than those predicted by ICAPM. The extent of the underweighting is shown in column 3, which presents the ratio of actual shares observed at end-1997 to the benchmark. ${ }^{14}$ Interestingly, there is a significant amount of variation in values

${ }^{14}$ This is equivalent to normalizing U.S. holdings in a country by the country's market capitalization and then dividing by a constant (the share of overall U.S. holdings in the worldwide market capitalization). 
across countries. ${ }^{15}$ For example, both the Netherlands and Mexico score roughly 0.44 , indicating that U.S. investors' holdings of stocks from these countries at end-1997 were 44 percent of what traditional portfolio theory would have predicted. On the other hand, the degree of underweighting appears more severe against countries such as Japan and Germany, where U.S. investors hold 12 and 15 percent, respectively, of the ICAPM levels.

We proceed by constructing a measure of U.S. investors' home bias against each country, defined as one minus the ratio of actual-to-benchmark holdings. Hence, a greater value of this measure corresponds to a higher degree of bias. Figure 2 presents this measure of home bias for our sample of the 48 largest foreign markets. The bias measure varies from 0.98 for China, where our holdings are 2 percent of the benchmark, to 0.44 for Ireland, where our holdings are 56 percent of the benchmark. Our main goal in this paper is to explain the distribution of this measure of U.S. investors' home bias across countries.

The final column in Table 1, which presents our data on the portion of firms in each country that are also listed on U.S. exchanges, will be discussed in the next section.

\section{Statistical Analysis}

This section explores possible determinants of the distribution of U.S. home bias across countries presented in Figure 2. The empirical specifications used in the paper are generally of the following form:

BIAS $_{\mathrm{i}}=\alpha+\beta \mathrm{X}_{\mathrm{i}}+\varepsilon_{\mathrm{i}}$

where BIAS is the degree of U.S. investors' home bias against country $i$ and $\mathrm{X}$ is a vector of independent variables that includes information costs, trade, transactions costs, capital controls, and historical risk-adjusted returns. The precise definitions of these variables and the reasons for including them in our regression equation will be discussed next.

${ }^{15}$ If the size of the foreign market was the only determinant of the country distribution of U.S. holdings, this measure would not vary across countries. 


\section{Description of Explanatory Variables}

Motivated by recent theoretical developments in the home bias literature and our discussion in Section II, we begin by exploring the importance of asymmetric information in accounting for variation in the degree of U.S. investors' home bias across countries. If asymmetric information is an important factor in explaining the home bias puzzle, then we would expect to see some correlation between variations in the degree of home bias across countries and proxies for informational segregation.

With this in mind, we construct a variable, USLISTED, that measures the share of a country's stock market that is listed on U.S. exchanges, either directly or as a Level 2 or Level 3 ADR. As discussed earlier, to the extent that listing on a U.S. exchange makes a foreign company's stock more attractive to U.S. investors by lowering information costs, we would expect U.S. investors to hold a relatively larger share of equities from countries that have higher shares of their stock markets listed on U.S. exchanges. Values for the shares of countries' stock markets that were listed on U.S. exchanges as of end-1997 are reported in the last column of Table 1. We note that the share of stocks that trade on U.S. exchanges varies widely by country, with the Netherlands leading the way at 81 percent, followed by Ireland, Portugal, and Argentina, which are each over 50 percent.

Figure 3 plots the share of each foreign country's stock market listed on U.S. exchanges versus the degree of home bias, BIAS. Recall that BIAS is one minus the ratio of actual to theoretical holdings; when BIAS is equal to zero there is no home bias, and as the measure increases the bias (or underweighting) is more severe. A striking feature of the pattern in Figure 3 is the strong negative correlation between a country's propensity to list on U.S. exchanges and the degree of bias; the correlation is negative 0.76 .

Another possible determinant of the distribution of bias across countries is international trade. For example, it may well be that by purchasing goods and services produced by foreign firms, U.S. investors glean information about these companies. At the very least, investors may be more inclined to hold the stocks of foreign companies with whose products they are most familiar. 
To control for the familiarity effects associated with trade, we include two measures of trade links. The first and broadest is TRADE, the amount of trade with the United States as a share of each country's GDP. This variable is plotted in Figure 4. Our second measure of trade links, FDI Sales, is perhaps more relevant from the perspective of information available to U.S. investors. When a foreign firm sets up operations in the United States, not only are U.S. investors more familiar with it products, but they may well work for the firm or live in the proximity of the plant. This represents an even greater familiarity with the firm. To capture this effect we use the data on sales by foreign direct investment (FDI) affiliates in the United States, again deflated by the foreign country's GDP. FDI Sales is available for only 32 of the 48 countries in our sample, and is shown in Figure 5. The difference between FDI Sales and other measures of trade links is highlighted by the values for the Netherlands. As a percent of GDP, trade with the United States is rather small for the Netherlands, but sales by Dutch affiliates in the United States are some 30 percent of Dutch GDP.

The measures discussed above represent indirect barriers to international investment. Direct barriers - such as capital controls - can also affect international portfolio decisions. While direct barriers have fallen considerably over the past few decades, they can still be important. For example, the time line in Bekeart and Harvey (1999) indicates that in 1997 foreign ownership restrictions for two of the largest Korean stocks, Korea Electric Power and Pohang Iron and Steel, were repeatedly binding, relaxed, and binding again.

Capital controls likely affect the distribution of home bias across countries; looking at Figure 2, it is probably not a coincidence that some of the countries U.S. investors underweight most (for example, China) maintain substantial barriers to foreign investment. One difficulty of including capital controls in our regression equation is that no widely accepted cross-country measure of foreign ownership restrictions suitable for empirical work currently exists. There are many measures of capital controls in the literature, ranging from dummy variable based on restrictions reported in the IMF's Annual Report on Exchange Arrangements and Exchange Restrictions to coefficient estimates from Feldstein-Horioka (1980) regressions to coefficients from excess returns regressions. 
In this paper we choose to piggyback on the work of the International Finance Corporation (IFC). Our measure of foreign ownership restrictions, RESTRICT, constructed using data from the IFC's emerging market indexes, is one minus the ratio of the market capitalizations of the IFC's Investable and Global indices. The Investable index is comprised of all stocks in the Global index that are deemed by the IFC to be available to foreign investors. Hence, if the market capitalizations of the two indexes are equal, there are no restrictions and our measure is zero. ${ }^{16}$ As shown in Figure 6, this measure varies greatly across developing countries, with about 10 percent of China's market available to foreigners in 1997, compared to 98 percent of South Africa's. ${ }^{17}$ In general, it is apparent from the figure that countries with more severe foreign ownership restrictions are more underweight in U.S. portfolios.

Finally, we consider the role of historical risk-adjusted returns. If portfolio decisions are based partly on past returns, then U.S. investors might tend to underweight countries whose stock markets have performed poorly. To capture this type of "returns-chasing" behavior, we construct a reward-to-risk ratio, shown in Figure 7, which is the mean monthly return over its standard deviation. As the figure shows, risk-adjusted returns were quite high for a number of European countries, but were negative for Japan and the East Asian crisis countries. The figure also appears to suggest a weak negative relationship between risk-adjusted returns and bias.

\section{Regression Results}

Our main results are presented in Table 2a. The top half of the table presents results for the 1997 survey; the bottom half is for the 1994 survey. The most striking feature of our results is that in every specification of our regression equation, there exists a strong negative relationship between BIAS and USLISTED. This result coincides with our prior, and we interpret it to mean

${ }^{16}$ See Edison and Warnock (2000) for a more complete discussion of this measure of foreign ownership restrictions and a comparison with other methods of quantifying capital controls.

${ }^{17}$ The IFC does not compute Investable indexes for industrial countries. Absent other information, we assume that for these countries the Investable and Global indexes are identical and, therefore, that foreign ownership restrictions are zero in industrial countries. 
that the reduction in information costs associated with listing on a U.S. exchange is an important determinant of the distribution of home bias across countries in our sample. The negative coefficient on USLISTED implies that countries whose firms do not alleviate information asymmetries by listing on a U.S. exchange are more severely underweighted in U.S. equity portfolios. We argued above that the information asymmetries may reflect differences in accounting standards, disclosure requirements, and regulatory environments across countries.

Focusing on the 1997 results, we see in column 2 that RESTRICT, our measure of foreign ownership restrictions, is negatively related to BIAS and is statistically significant. As expected, U.S. investors are more underweight against countries with more extensive foreign ownership restrictions. Both measures of trade links, TRADE and FDI Sales, have the expected sign (columns 3 and 4), but neither is statistically significant. While it is true that U.S. investors are less underweight against the two countries most closely linked to the United States, Mexico and Canada, on average we find no significant relationship between trade and home bias. ${ }^{18}$ The use of alternative measures of trade links--for example, U.S. imports from each country as a share of that country's GDP--does not alter this result. ${ }^{19}$ Our measure of risk-adjusted returns, REWRISK, turns up positively related to BIAS, but with a t-statistic near zero.

Returning to the USLISTED variable, roughly speaking, the estimated value of the coefficient on this variable in column 3 implies that if, for example, German firms were listed on U.S. exchanges to the same extent as Dutch firms, we would expect the bias against Germany to be significantly lower, falling from 0.85 to 0.57 .

${ }^{18}$ This contrasts with the results of Honohan and Lane (2000), who find that trade is the main determinant of the composition of Ireland's foreign securities portfolio.

${ }^{19}$ Obstfeld and Rogoff (2000) construct a two-country model in which trade costs in goods markets give rise to home bias in both portfolio and consumption decisions. In their model, equilibrium portfolio shares are proportional to consumption shares, and home bias arises because households face "iceberg" costs of trade on goods shipped abroad. Extending this intuition into a multi-country framework, we suspect that any explanation of home bias based on trading costs in goods markets would likely imply a positive correlation between U.S. purchases of foreign equities and goods across countries, an implication seemingly at odds with our finding that trade links are unrelated to home bias. 
Our results appear robust across the two sample dates. For 1994, the story is very similar to 1997, although REWRISK and FDI Sales, while still not significant, gain some explanatory power. USLISTED is still positive and explains about 50 percent of the variation in home bias. Trade remains insignificant. ${ }^{20}$

In Tables $2 b-2 d$ we present a series of robustness checks in which the sample is limited to countries with particular characteristics. In Table $2 \mathrm{~b}$ we restrict the sample to those countries that have at least one listing on a U.S. exchange. For the 1997 regressions, dropping the ten countries without U.S. listings does not substantially affect the results: A little over 50 percent of the variation in home bias is explained by USLISTED, RESTRICT has some explanatory power, and the measures of trade links and REWRISK have no explanatory power. In 1994, only 27 countries had listings on U.S. exchanges. Possibly because of this sharply reduced sample size, the results for the 1994 regressions reported in Table $2 \mathrm{~b}$ are noticeably different than those reported in Table 2a. Specifically, RESTRICT loses its explanatory power--possibly because most of the countries with foreign ownership restrictions did not have U.S. listings in 1994 and thus were not included in the regression--as do FDI Sales and REWRISK.

In Tables 2c, we limit the sample to those countries with foreign ownership restrictions, effectively all of the developing countries in our sample. ${ }^{21}$ In Table $2 \mathrm{c}$ we see that among countries with foreign ownership restrictions, trade links seem to matter more, at least for the 1997 regressions. Somewhat surprisingly, in 1997, among this group of developing countries, U.S. investors seemed to favor countries with lower reward-to-risk ratios. The results for 1994 regressions for these countries are qualitatively similar to those for the full sample (Table 2a): RESTRICT regains its explanatory power, trade becomes insignificant, and FDI Sales and REWRISK are once again significant and negative. Since the sample size is quite small in these regressions, the results should be interpreted cautiously.

${ }^{20}$ It is perhaps interesting to note that Warnock and Mason (2000) find that if bias is computed using holdings estimated from transactions data and valuation adjustments, trade becomes significant. restrictions.

${ }^{21}$ The one exception is Poland, a developing country that had no foreign ownership 
Table $2 \mathrm{~d}$ presents results with the sample limited to those countries without foreign ownership restrictions. The results for this group of developed countries are broadly consistent with those from Tables $2 \mathrm{a}$ and 2c: USLISTED is highly significant, FDI Sales is marginally significant, and TRADE and REWRISK are insignificant. Some differences are noticeable. For example, the point estimates for USLISTED are consistently smaller than for the developing countries (Table 2c), although the differences are not statistically significant. Once again, we caution that the sample sizes in these regressions are small.

In Table 3 we examine the extent to which we can explain changes in home bias from 1994 to 1997. Given the results for the levels regressions, we focus on USLISTED and do not report results for the other explanatory variables. Controlling for the initial (1994) levels of bias and U.S. listings, we generally find that the greater the increase in listings between 1994 and 1997, the greater is the reduction in bias. More specifically, the results in Table 3 show that the decrease in bias over the 1994 to 1997 period is greatest for countries that had a high degree of bias and low amount of U.S. listings in 1994 and subsequently increased U.S. listings.

Not all variables are significant in every sample in Table 3. For example, an increase in U.S. listings is associated with a decrease in bias in every sample but the one limited to industrial countries (column 3). The level of U.S. listing in 1994 matters for this sample, but not for the one consisting of only countries with listings in the United States. The one variable that is significant across samples is the 1994 level of bias, suggesting that there was some catching up in the 1994-1997 period: The more underweight were U.S. investors in a country in 1994, the greater was the move towards the ICAPM benchmark from 1994 to 1997.

\section{Caveats}

We note that the main independent variable in our regression equations, the portion of the foreign market that is cross-listed on U.S. exchanges, might be endogenous. Due to the high costs involved with listing in the United States, only firms that anticipate that the listing will be met by strong investor demand will choose to list. For example, the listing fee alone can be $\$ 2$ million on the NYSE, on top of which must be added the considerable costs of reconciling financial accounts with U.S. GAAP, costs that can amount to greater than $\$ 1$ million for large 
firms from industrial countries. Hence, it could be argued that the causality goes from prospective U.S. demand to U.S. listings. However, we would argue that this prospective demand is conditional on listing on a U.S. exchange. Supporting our view is the evidence that foreign stocks experience abnormal returns just after the announcement of a U.S. listing (Miller,1999) and during the process of regulatory and exchange approval (Foerster and Karolyi, 1999); if U.S. demand was already present, abnormal returns should not be evident.

It may also be that third factors determine both bias and listing. We control for some of these in our regressions. For example, firms that have high ratios of U.S. to total sales may be more likely to list here, and U.S. investors may naturally have more information on these firms and hence may be more likely to hold their stocks. Evidence supporting the first link, from high foreign sales to cross-listing, is provided by Pagano, Roell, and Zechner (1999) and Sarkissian and Schill (1999). ${ }^{22}$ We controlled for this familiarity effect by including measures of trade links and sales by foreign affiliates in the United States.

\section{Extensions}

In this section we extend our analysis to directly address the roles of transaction costs, accounting standards, and regulatory environments in the country distribution of U.S. investors' home bias. Due to data and degrees of freedom limitations, these variables are not included in the main regressions reported above.

\section{Transaction Costs}

The role of transaction costs in home bias has been downplayed in the literature. For example, French and Poterba (1991) and Cooper and Kaplanis (1986) conclude that costs would have to be implausibly high to explain the observed home bias. Moreover, Tesar and Werner (1995) provide evidence that investors turn over their foreign portfolios more frequently than their domestic portfolios, which is inconsistent with transaction costs being large enough to

\footnotetext{
${ }^{22}$ Other studies on why firms cross-list are Karolyi (1998) and Saudagaran (1988).
} 
significantly impede international investment. ${ }^{23}$ None of these studies, however, use data on transaction costs to reach their conclusions, perhaps because such data did not exist across a wide range of countries until 1996.

To control for the effects of transaction costs we use the Elkins-McSherry Co. measure of trading costs across 41 foreign markets. This measure, shown in Figure 8 and analyzed in Willoughby (1997) and Domowitz, Glen, and Madhaven (2000), is comprised of three components: commissions, fees, and market impact costs. ${ }^{24}$ As the figure shows, it is difficult to discern a relationship between trading costs and our measure of bias across the 41 countries for which the measure is available. Among all but the highest cost countries, however, it does appear that higher cost countries are more underweight in U.S. portfolios.

Table 4 analyzes the effects of trading costs on home bias more formally. In bivariate regressions, trading costs are either insignificantly different from zero (with t-stats less than 0.5) or, in the sample limited to industrial countries (column 3), negative and significant. That is, the simple bivariate relationship suggests that higher cost developed countries are less underweight in U.S. portfolios, but that in the full sample and other cuts of the data, no relationship is apparent.

Since trading costs are low on the NYSE--the U.S. exchange on which over 80 percent (by market capitalization) of non-U.S. stocks are listed--firms from high cost countries can effectively lower trading costs in their stock and, hence, broaden their shareholder base by listing in the United States. To capture the effect of the reduction in trading costs associated with a U.S. listing, Table 4 also reports regressions that include an interaction term combining (one minus) costs and listings. Costs are still not positive and significant in these regressions, but the positive coefficient on the interaction term (in all but the developing country regression, which suffers from collinearity) is evidence that high cost countries with a high portion of U.S. listings are less

\footnotetext{
${ }^{23}$ High turnover rates on foreign equity portfolios are not evident using updated holdings estimates; see footnote 6 .

${ }^{24}$ Market impact costs, or liquidity costs, are intended to measure the deviation of the transaction price from the price that would have prevailed had the trade not occurred; see Willoughby (1998) for a discussion.
} 
underweight in U.S. portfolios. That is, countries whose firms tend to list on U.S. exchanges are less underweight in U.S. portfolios and high cost countries get an extra boost in U.S. portfolios from the listing. Overall, the results in Table 4 indicate that one way that listing on a U.S. exchange, particularly on the NYSE, reduces home bias is through reduced transaction costs.

\section{Accounting Standards}

While listing on U.S. exchanges tends to reduce home bias to some extent through lower transaction costs, this cannot explain why U.S. investors' bias is severe against countries with low trading costs. The story we tell in this paper is one in which a U.S. listing helps alleviate information costs borne by U.S. investors due to differences in accounting standards, disclosure requirements, and regulatory environments across countries. Direct testing of this hypothesis is difficult for a number of reasons. First, any numeric scoring of accounting standards across countries is likely inadequate for our purposes. For example, these measures are calculated based on the inclusion or omission of certain items, but these items vary in importance across sectors. ${ }^{25}$ Second, as Fuerst (1998) puts it, it is not just the information itself -- Harris et al (1998) shows us how to compare information generated from different accounting standards -- but its credibility.

We use the measure of the quality of accounting standards presented by La Porta, Lopezde-Silanes, Shleifer, and Vishny (1998), available for 37 countries in our sample. These measures are imperfect for our purpose because they are based on 1990 standards and do not include differences in disclosure requirements, but are nonetheless useful. Since high accounting standards do not likely improve the quality of information available to investors if the regulatory environment is lax, we also include a broad measure of the rule of law, which we take from the same source. Preferable would be a measure of the extent to which securities laws are enforced.

Since the accounting standards measure, ACCT, is only available for 1990 and standards have changed in many countries in the 1990s, we only analyze the 1994 level of bias in this section. The first two columns of Table 5 indicate that while there is only weak evidence that higher accounting standards are associated with less bias, the evidence is stronger that countries

\footnotetext{
${ }^{25}$ We thank Trevor Harris for bringing this point to our attention.
} 
with higher scores on rule of law (ROL) are less underweight in U.S. portfolios. When we include USLISTED (column 3), the t-statistics on ACCT and ROL fall toward zero. In the fourth column we include interaction terms. The story that emerges is that countries that are less underweight in U.S. portfolios (i) tend to list on U.S. exchanges, (ii) have both high accounting standards and high scores on rule of law, (iii) have low accounting standards but list on U.S exchanges. That the interaction of high standards and high rule of law is associated with lower bias, but that by themselves accounting standards and rule of law have positive coefficients, underscores the importance of the credibility of the information, not just the quantity.

\section{Conclusion}

The results presented in this paper suggest that information costs are an important factor behind the home bias phenomenon. To list on a U.S. stock exchange, a foreign firm must reconcile its financial statements with U.S. GAAP, comply with stringent SEC disclosure requirements, and subject itself to the strict U.S. regulatory environment. Doing so alleviates a significant information cost to the U.S. investor. We find, based on a comprehensive data set of U.S. holdings of foreign equities, that countries with a greater share of firms that list on U.S. exchanges, either directly or as exchange-traded ADRs, tend to be less severely underweighted in U.S. equity portfolios. We find that this effect is much stronger than the effects of trade links or direct barriers such as foreign ownership restrictions. We also find some evidence that firms from countries with low accounting standards or high trading costs can improve their prospects with U.S. investors by listing on a U.S. exchange.

We restricted our focus in this paper to the determinants of U.S. investors holdings of foreign equities. One avenue for future research might be to consider a broader class of assets, including, for example, U.S. investors holdings of foreign bonds, both sovereign and corporate. Along these same lines, an even more wide-ranging study of U.S. investors' exposure to foreign economies might include cross-border bank lending as well as U.S. investors' holdings of equities of U.S. multinationals. Moreover, while our focus was on U.S. portfolios, it would also be interesting to explore other countries' foreign portfolios. 


\section{Bibliography}

Baker, H.K., J. Nofsinger, and D. Weaver, 2000. International cross listing and visibility. mimeo American University.

Bekaert, G., and C.R. Harvey, 1999. Capital Flows and the Behavior of Emerging Market Equity Returns, in S. Edwards, Capital Inflows to Emerging Markets, NBER and University of Chicago Press.

Black, F., 1974. International capital market equilibrium with investment barriers. Journal of Financial Economics, 1.

Bordo, M., B. Eichengreen, and D. Irwin, 1999. Is globalization today really different than globalization a hundred years ago? in S. Collins an R. Lawrence, eds., Brookings Trade Forum 1999, Brookings Institution Press.

Breeden, R., 1994. Foreign companies and U.S. securities markets in a time of economic transformation. Fordham International Law Journal, 17: S77-96.

Cooper, I., and E. Kaplanis, 1986. Costs to crossborder investment and international equity market equilibrium. in J. Edwards, J. Franks, C. Mayer and S. Schaefer (eds.), Recent Developments in Corporate Finance. Cambridge University Press, Cambridge.

Cooper, I., and E. Kaplanis, 1994. What explains the home bias in portfolio investment? Review of Financial Studies, 7: 45-60.

Coval, J., and T. Moskowitz, 1999. Home bias at home: Local equity preference in domestic portfolios. Journal of Finance, 54(6).

Domowitz, I., J. Glen, and A. Madhaven, 2000. Liquidity, volatility, and equity trading costs across countries and over time. mimeo.

Edison, H., and F. Warnock, 2000. The Effects of Capital Controls on Equity Flows to Emerging Markets. Federal Reserve Board, mimeo.

Feldstein, M., and C. Horioka, 1980. Domestic savings and international capital flows. Economic Journal, 90: 314-329.

Foerster, S., and G.A. Karolyi, 1999. The effects of market segmentation and investor recognition on asset prices: evidence from foreign stocks listing in the U.S. Journal of Finance, 54(3). 
French, K., and J. Poterba, 1991. Investor diversification and international equity markets. American Economic Review, Papers and Proceedings, 222-226.

Fuerst, O., 1998. A theoretical analysis of the investor protection regulations argument for global listing of stocks. International Center for Finance at Yale.

Harris, T., 1998. Overcoming Accounting Differences: A stockpicker's guide to the numbers that count. Apples to Apples Series, Morgan Stanley Dean Witter.

Honohan, P., and P. Lane, forthcoming. Where do the Irish invest? Irish Banking Review. International Finance Corporation, 1998. Emerging Stock Markets Factbook 1998, IFC.

Kang, J., and R. Stulz, 1997. Why is there a home bias? An analysis of foreign portfolio equity ownership in Japan, Journal of Financial Economics, 46:3-28.

Karolyi, G.A., 1998. Why do companies list shares abroad?: A survey of the evidence and its managerial implications. Financial Markets, Institutions \& Instruments, 7(1).

La Porta, R., F. Lopez-de-Silanes, A. Shleifer, and R. Vishny, 1998. Law and finance. Journal of Political Economy, 106: 1113-1155.

La Porta, R., F. Lopez-de-Silanes, and A. Shleifer, 1999. Corporate Ownership Around the World. Journal of Finance, 54(2).

Lewis, K., 1999. Trying to explain the home bias in equities and consumption. Journal of Economic Literature, 37:571-608.

Lins, K., D. Strickland, and M. Zenner. Do non-U.S. firms issue equity on U.S. stock exchanges to relax capital constraints? Working Paper, Ohio State University.

Lintner, J., 1965. The valuation of risky assets and the selection of risky investment in stock portfolio and capital budgets. Review of Economics and Statistics, 47: 103-124.

Miller, D., 1999. The market reaction to international cross-listings: evidence from Depositary Receipts. Journal of Financial Economics, 51: 103-123.

Obstfeld, M., and K. Rogoff, 2000. The six major puzzles in international macroeconomics: Is there a common cause? NBER Working Paper 7777.

Pagano, M., A. Roell, and J. Zechner, 1999. The geography of equity listing: Why do european companies list abroad? Working Paper, Princeton University. 
Portes, R., and H. Rey, 1999. The determinants of cross-border equity flows: the geography of information. NBER Working Paper 7336.

Sarkissian, S., and M. Schill, 1999. The overseas listing decision: New evidence of proximity preference. Working paper, McGill University.

Saudagaran, S., 1988. An empirical study of selected factors influencing the decision to list on foreign stock exchanges, Journal of International Business Studies, 19: 101-127.

Sharpe, W., 1964. Capital asset prices: A theory of market equilibrium under the condition of risk. Journal of Finance, 19: 425-442.

Stulz, R., 1981. On the effects of barriers to international investment. Journal of Finance, 36: 923-934.

Stulz, R., 1999. Globalization of equity markets and the cost of capital. Paper prepared for the SBF/NYSE Conference on Global Equity Markets.

Tesar, L., and I. Werner, 1995. Home bias and high turnover. Journal of International Money and Finance, 14: 467-493.

Treasury Department, 1998. Report on Foreign Portfolio Investment in the United States as of December 31, 1997.

Treasury Department and Federal Reserve Board, 2000. United States Holdings of Foreign Long-Term Securities as of December 31, 1997 and December 31, 1999.

Warnock, F., 2000. Home bias and high turnover: comment. Federal Reserve Board, mimeo.

Warnock, F., and M. Mason, 2000. The geography of capital flows: what we can learn from benchmark surveys of foreign equity holdings. Federal Reserve Board, International Finance Discussion Paper 688.

Willoughby, J., 1997. Trade secrets. Institutional Investor.

Willoughby, J., 1998. Executions Song. Institutional Investor, 31(11), 51-56.

White, H., 1980. A Heteroskedasticity-Consistent Covariance Matrix Estimator and Direct Test for Heteroskedasticity. Econometrica, 48: 817-838. 


\section{Data Appendix}

We include the 48 largest countries (excluding the United States) by 1997 market capitalization. The smallest country in sample is Pakistan (market capitalization of $\$ 11$ billion); the largest country excluded is Oman ( $\$ 7$ billion). Data exist for most variables for each of these countries, unless noted.

U.S. holdings of foreign equities are available at www.treas.gov/fpis/ for March 1994 and December 1997.

Data on worldwide market capitalizations of non-U.S. stocks listed on U.S. stock markets are compiled from various sources. For NYSE-listed firms, year-end data were provided by the NYSE, compiled from data from FactSet and Bloomberg. For the 1994Q1 regressions, we use end-1993 NYSE values. Data for non-U.S. firms listed on Nasdaq and Amex are from CompuStat. For all ADRs in the 1997 sample, cross-checks were made using Bank of New York (BONY) ADR Index data for 1998.

Country-level market capitalization data, which are of domestic firms listed on the domestic market, are from IFC Emerging Markets Factbook 1998 and the International Federation of Stock Exchanges (www.fibv.com). The coverage of IFC is better; FIBV data were used as a crosscheck. Differences between the two sources were for the most part small or nonexistant, except for in the data for Ireland, Australia, and New Zealand, where the IFC number was based on an incorrect currency conversion.

Trade data are from IMF Direction of Trade Statistics Yearbook, 1999.

FDI Sales data, available for 32 countries, are from the BEA Survey of Current Business, Tables 23.2 (August 1999) and 21.1 (July 1996) Selected Data of Nonbank U.S. Affiliates by Country of Ultimate Beneficial Owner.

The measure of foreign ownership restrictions is one minus the ratio of the market capitalizations of the IFC Investable and Global Indexes (IFC, 1998). The measure is assumed to be zero for industrial countries that do not have IFCI indexes.

Transaction costs for 41 countries are from Elkin-McSherry Co. (www.elkins-mcsherry.com).

Reward/risk is the mean return over the standard deviation of returns, where returns are changes in the country's MSCI Price Index calculated over the periods of 15 quarters preceding 1994Q1 and 1997Q4. Data were obtained from www.mscidata.com.

Accounting standards are for 1990 as compiled by the Center for International Financial Analysis and Research. Rule of law is for 1982 to 1995 as compiled by the International Country Risk rating agency. Both are taken from La Porta et al (1998). 
Table 1

U.S. Portfolio Holdings and International Stock Market Measures (as of end-1997)

\begin{tabular}{|c|c|c|c|c|}
\hline Country & $\begin{array}{c}\text { Actual U.S. } \\
\text { Holdings } \\
\text { (\% of total U.S. } \\
\text { holdings) }\end{array}$ & $\begin{array}{c}\text { Benchmark } \\
\text { (\% of world market } \\
\text { capitalization) }\end{array}$ & $\begin{array}{l}\text { Actual over } \\
\text { Benchmark }\end{array}$ & $\begin{array}{l}\text { U.S. Listed } \\
\text { (\% of market } \\
\text { capitalization) }\end{array}$ \\
\hline \multicolumn{5}{|l|}{$\begin{array}{l}\text { Major industrial } \\
\text { countries }\end{array}$} \\
\hline United States & 89.9 & 48.3 & 1.86 & 100.0 \\
\hline United Kingdom & 1.82 & 8.5 & .21 & 38.7 \\
\hline Japan & 1.14 & 9.4 & .12 & 27.2 \\
\hline France & 0.71 & 2.9 & .25 & 29.3 \\
\hline Canada & 0.59 & 2.4 & .25 & 44.4 \\
\hline Germany & 0.54 & 3.5 & .15 & 17.6 \\
\hline Italy & 0.35 & 1.5 & .24 & 42.5 \\
\hline \multicolumn{5}{|l|}{$\begin{array}{l}\text { Other advanced } \\
\text { countries }\end{array}$} \\
\hline Netherlands & 0.89 & 2.0 & .45 & 80.7 \\
\hline Switzerland & 0.52 & 2.5 & .21 & 1.3 \\
\hline Sweden & 0.32 & 1.2 & .28 & 34.0 \\
\hline Spain & 0.21 & 1.2 & .17 & 39.2 \\
\hline Ireland & 0.12 & 0.2 & .56 & 64.2 \\
\hline Finland & 0.12 & 0.3 & .40 & 32.4 \\
\hline Norway & 0.08 & 0.3 & .28 & 23.1 \\
\hline Denmark & 0.07 & 0.4 & .19 & 21.5 \\
\hline Portugal & 0.06 & 0.2 & .35 & 61.9 \\
\hline Israel & 0.06 & 0.2 & .31 & 41.5 \\
\hline
\end{tabular}


Table 1 (continued)

U.S. Portfolio Holdings and International Stock Market Measures as of end-1997

\begin{tabular}{|c|c|c|c|c|}
\hline Country & $\begin{array}{c}\text { Actual U.S. } \\
\text { Holdings } \\
\text { (\% of total U.S. } \\
\text { holdings) }\end{array}$ & $\begin{array}{c}\text { Benchmark } \\
\text { (\% of world market } \\
\text { capitalization) }\end{array}$ & $\begin{array}{l}\text { Actual over } \\
\text { Benchmark }\end{array}$ & $\begin{array}{l}\text { U.S. Listed } \\
\text { (\% of market } \\
\text { capitalization) }\end{array}$ \\
\hline Belgium & 0.05 & 0.6 & .09 & 7.2 \\
\hline Luxembourg & 0.04 & 0.1 & .31 & 26.0 \\
\hline Austria & 0.03 & 0.2 & .20 & 0.0 \\
\hline Greece & 0.01 & 0.2 & .09 & 0.4 \\
\hline Australia & 0.26 & 1.3 & .21 & 42.7 \\
\hline Hong Kong & 0.23 & 1.8 & .13 & 10.0 \\
\hline Singapore & 0.09 & 0.5 & .19 & 4.5 \\
\hline Taiwan & 0.04 & 1.2 & .03 & 5.5 \\
\hline Korea & 0.04 & 0.2 & .21 & 24.5 \\
\hline New Zealand & 0.04 & 0.1 & .35 & 42.7 \\
\hline \multicolumn{5}{|l|}{$\begin{array}{l}\text { Developing } \\
\text { Countries }\end{array}$} \\
\hline \multicolumn{5}{|l|}{ Latin America } \\
\hline Mexico & 0.29 & 0.7 & .44 & 33.6 \\
\hline Brazil & 0.26 & 1.1 & .24 & 24.1 \\
\hline Argentina & 0.11 & 0.3 & .43 & 56.5 \\
\hline Chile & 0.04 & 0.3 & .12 & 38.9 \\
\hline Peru & 0.02 & 0.1 & .26 & 38.6 \\
\hline Venezuela & 0.02 & 0.1 & .27 & 13.3 \\
\hline
\end{tabular}


Table 1 (continued)

U.S. Portfolio Holdings and International Stock Market Measures as of end-1997

\begin{tabular}{|c|c|c|c|c|}
\hline Country & $\begin{array}{c}\text { Actual U.S. } \\
\text { Holdings } \\
\text { (\% of total U.S. } \\
\text { holdings) }\end{array}$ & $\begin{array}{c}\text { Benchmark } \\
\text { (\% of world market } \\
\text { capitalization })\end{array}$ & $\begin{array}{l}\text { Actual over } \\
\text { Benchmark }\end{array}$ & $\begin{array}{l}\text { U.S. Listed } \\
\text { (\% of market } \\
\text { capitalization) }\end{array}$ \\
\hline Colombia & 0.01 & 0.1 & .07 & 10.2 \\
\hline \multicolumn{5}{|l|}{ Asia } \\
\hline India & 0.05 & 0.6 & .09 & 0.0 \\
\hline Malaysia & 0.04 & 0.4 & .10 & 0.0 \\
\hline Indonesia & 0.02 & 0.1 & .17 & 20.0 \\
\hline Phillippines & 0.02 & 0.1 & .18 & 6.5 \\
\hline China & 0.02 & 0.9 & .02 & 1.3 \\
\hline Thailand & 0.02 & 0.1 & .18 & 0.0 \\
\hline Pakistan & 0.01 & 0.1 & .21 & 0.0 \\
\hline \multicolumn{5}{|l|}{$\begin{array}{l}\text { Central and } \\
\text { eastern Europe }\end{array}$} \\
\hline Russia & 0.07 & 0.5 & .13 & 0.7 \\
\hline Hungary & 0.03 & 0.1 & .46 & 33.3 \\
\hline Czech Republic & 0.01 & 0.1 & .12 & 0.0 \\
\hline Poland & 0.01 & 0.1 & .26 & 0.0 \\
\hline
\end{tabular}


Table 1 (continued)

U.S. Portfolio Holdings and International Stock Market Measures as of end-1997

\begin{tabular}{|l|c|c|c|c|}
\hline Country & $\begin{array}{c}\text { Actual U.S. } \\
\text { Holdings } \\
\text { (\% of total U.S. } \\
\text { holdings })\end{array}$ & $\begin{array}{c}\text { Benchmark } \\
\text { (\% of world market } \\
\text { capitalization) }\end{array}$ & $\begin{array}{c}\text { Actual over } \\
\text { Benchmark }\end{array}$ & $\begin{array}{c}\text { U.S. Listed } \\
\text { (\% of market } \\
\text { capitalization) }\end{array}$ \\
\hline $\begin{array}{l}\text { Other } \\
\text { Developing }\end{array}$ & & & .08 & \\
\hline South Africa & 0.08 & 1.0 & .19 & 0.0 \\
\hline Turkey & 0.05 & 0.3 & .07 & 0.0 \\
\hline Egypt & 0.01 & 0.1 & .04 & 0.0 \\
\hline Morocco & 0.01 & 0.1 & & \\
\hline & & & & \\
\hline
\end{tabular}

Sources: Treasury Department and Federal Reserve Board (2000); International Finance Corporation (1998); NYSE; CompuStat; authors' calculations.

Definitions: Actual U.S. Holdings refers to country's share of U.S. equity holdings; ICAPM Benchmark refers to portfolio shares predicted by ICAPM, i.e. shares determined by country market capitalization; U.S. Listed refers to share of country's stock market that is listed on U.S. exchanges. 
Table 2a

Results: Full Sample

\begin{tabular}{|c|c|c|c|c|c|}
\hline & (1) & (2) & (3) & (4) & (5) \\
\hline & \multicolumn{4}{|c|}{1997} & \\
\hline USLISTED & $\begin{array}{l}-0.43^{* * *} \\
(0.06)\end{array}$ & $\begin{array}{l}-0.39^{* * *} \\
(0.06)\end{array}$ & $\begin{array}{l}-0.39^{* * *} \\
(0.06)\end{array}$ & $\begin{array}{l}-0.41^{* * *} \\
(0.08)\end{array}$ & $\begin{array}{l}-0.37^{* * *} \\
(0.06)\end{array}$ \\
\hline RESTRICT & & $\begin{array}{c}0.08^{* *} \\
(0.04)\end{array}$ & $\begin{array}{c}0.08^{* *} \\
(0.04)\end{array}$ & $\begin{array}{c}0.08^{*} \\
(0.05)\end{array}$ & $\begin{array}{c}0.09^{*} \\
(0.05)\end{array}$ \\
\hline TRADE & & & $\begin{array}{l}-0.08 \\
(0.12)\end{array}$ & & $\begin{array}{l}-0.10 \\
(0.13)\end{array}$ \\
\hline FDI SALES & & & & $\begin{array}{l}-0.12 \\
(0.13)\end{array}$ & \\
\hline REWRISK & & & & & $\begin{array}{c}0.01 \\
(0.08)\end{array}$ \\
\hline $\mathrm{N}$ & 48 & 48 & 48 & 32 & 43 \\
\hline \multirow[t]{2}{*}{ Adjusted $\mathrm{R}^{2}$} & 0.52 & 0.53 & 0.53 & 0.53 & 0.49 \\
\hline & \multicolumn{4}{|c|}{1994} & \\
\hline USLISTED & $\begin{array}{l}-0.56^{* * *} \\
(0.07)\end{array}$ & $\begin{array}{l}-0.47^{* * *} \\
(0.07)\end{array}$ & $\begin{array}{l}-0.48^{* * *} \\
(0.08)\end{array}$ & $\begin{array}{l}-0.42^{* * *} \\
(0.07)\end{array}$ & $\begin{array}{l}-0.46^{* * *} \\
(0.07)\end{array}$ \\
\hline RESTRICT & & $\begin{array}{c}0.08^{* *} \\
(0.04)\end{array}$ & $\begin{array}{c}0.08^{* *} \\
(0.04)\end{array}$ & $\begin{array}{c}0.06 \\
(0.05)\end{array}$ & $\begin{array}{c}0.10^{* *} \\
(0.05)\end{array}$ \\
\hline TRADE & & & $\begin{array}{l}-0.09 \\
(0.13)\end{array}$ & & $\begin{array}{c}0.02 \\
(0.10)\end{array}$ \\
\hline FDI SALES & & & & $\begin{array}{l}-0.21 \\
(0.16)\end{array}$ & \\
\hline REWRISK & & & & & $\begin{array}{l}-0.18 \\
(0.13)\end{array}$ \\
\hline $\mathrm{N}$ & 44 & 39 & 39 & 27 & 31 \\
\hline Adjusted $\mathrm{R}^{2}$ & 0.51 & 0.54 & 0.53 & 0.50 & 0.58 \\
\hline
\end{tabular}

Notes. Dependent variable is BIAS. Constants are included but not reported. USLISTED is the share of the foreign market that is cross-listed on U.S. exchanges. RESTRICT is a measure of foreign ownership restrictions; see text for description. TRADE and FDI SALES are expressed as a share of the foreign country's GNP. REWRISK is the mean over standard deviation of monthly returns calculated over a 15 -quarter period. White (1980) standard errors are in parentheses. ${ }^{* * * * *}$, and ${ }^{*}$ indicate significance at the $1 \%, 5 \%$, and $10 \%$ levels, respectively. 
Table 2b

Results: Sample Limited to Countries with Listings on U.S. Exchanges

\begin{tabular}{|c|c|c|c|c|c|}
\hline & (1) & (2) & (3) & (4) & (5) \\
\hline & \multicolumn{4}{|c|}{1997} & \\
\hline USLISTED & $\begin{array}{l}-0.48^{* * *} \\
(0.06)\end{array}$ & $\begin{array}{l}-0.45^{* * *} \\
(0.07)\end{array}$ & $\begin{array}{l}-0.45^{* * *} \\
(0.06)\end{array}$ & $\begin{array}{l}-0.43^{* * *} \\
(0.09)\end{array}$ & $\begin{array}{l}-0.43^{* * *} \\
(0.09)\end{array}$ \\
\hline RESTRICT & & $\begin{array}{c}0.08^{*} \\
(0.04)\end{array}$ & $\begin{array}{c}0.09^{* *} \\
(0.04)\end{array}$ & $\begin{array}{c}0.07 \\
(0.05)\end{array}$ & $\begin{array}{c}0.07 \\
(0.05)\end{array}$ \\
\hline TRADE & & & $\begin{array}{l}-0.15 \\
(0.15)\end{array}$ & & $\begin{array}{l}-0.19 \\
(0.16)\end{array}$ \\
\hline FDI SALES & & & & $\begin{array}{l}-0.14 \\
(0.14)\end{array}$ & \\
\hline REWRISK & & & & & $\begin{array}{l}-0.05 \\
(0.08)\end{array}$ \\
\hline $\mathrm{N}$ & 38 & 38 & 38 & 30 & 36 \\
\hline \multirow[t]{2}{*}{ Adjusted $\mathrm{R}^{2}$} & 0.53 & 0.53 & 0.54 & 0.53 & 0.57 \\
\hline & \multicolumn{4}{|c|}{1994} & \\
\hline USLISTED & $\begin{array}{l}-0.49^{* * *} \\
(0.08)\end{array}$ & $\begin{array}{l}-0.45^{* * *} \\
(0.07)\end{array}$ & $\begin{array}{l}-0.47^{* * *} \\
(0.10)\end{array}$ & $\begin{array}{l}-0.41^{* * *} \\
(0.10)\end{array}$ & $\begin{array}{l}-0.45^{* * *} \\
(0.10)\end{array}$ \\
\hline RESTRICT & & $\begin{array}{c}0.05 \\
(0.07)\end{array}$ & $\begin{array}{c}0.05 \\
(0.07)\end{array}$ & $\begin{array}{c}0.01 \\
(0.08)\end{array}$ & $\begin{array}{c}0.10 \\
(0.11)\end{array}$ \\
\hline TRADE & & & $\begin{array}{l}-0.14 \\
(0.15)\end{array}$ & & $\begin{array}{l}-0.01 \\
(0.11)\end{array}$ \\
\hline FDI SALES & & & & $\begin{array}{l}-0.20 \\
(0.20)\end{array}$ & \\
\hline REWRISK & & & & & $\begin{array}{l}-0.15 \\
(0.17)\end{array}$ \\
\hline $\mathrm{N}$ & 27 & 25 & 25 & 21 & 23 \\
\hline Adjusted $\mathrm{R}^{2}$ & 0.45 & 0.45 & 0.44 & 0.37 & 0.42 \\
\hline
\end{tabular}

Notes. Dependent variable is BIAS. Constants are included but not reported. USLISTED is the share of the foreign market that is cross-listed on U.S. exchanges. RESTRICT is a measure of foreign ownership restrictions; see text for description. TRADE and FDI SALES are expressed as a share of the foreign country's GNP. REWRISK is the mean over standard deviation of monthly returns calculated over a 15-quarter period. White (1980) standard errors are in parentheses. ${ }^{* * * * *}$, and ${ }^{*}$ indicate significance at the $1 \%, 5 \%$, and $10 \%$ levels, respectively. 
Table 2c

Results: Sample Limited to Countries with Foreign Ownership Restrictions

\begin{tabular}{|c|c|c|c|c|c|}
\hline & (1) & (2) & (3) & (4) & (5) \\
\hline & \multicolumn{4}{|c|}{1997} & \\
\hline USLISTED & $\begin{array}{l}-0.51^{* * *} \\
(0.08)\end{array}$ & $\begin{array}{l}-0.47^{* * *} \\
(0.08)\end{array}$ & $\begin{array}{l}-0.48^{* * *} \\
(0.08)\end{array}$ & $\begin{array}{l}-0.71 \text { *** } \\
(0.18)\end{array}$ & $\begin{array}{l}-0.50^{* * *} \\
(0.09)\end{array}$ \\
\hline RESTRICT & & $\begin{array}{c}0.05 \\
(0.05)\end{array}$ & $\begin{array}{c}0.05 \\
(0.06)\end{array}$ & $\begin{array}{c}0.05 \\
(0.05)\end{array}$ & $\begin{array}{c}0.07 \\
(0.06)\end{array}$ \\
\hline TRADE & & & $\begin{array}{l}-0.24^{*} \\
(0.14)\end{array}$ & & $\begin{array}{l}-0.28 \\
(0.15)\end{array}$ \\
\hline FDI SALES & & & & $\begin{array}{l}-0.30 \\
(0.22)\end{array}$ & \\
\hline REWRISK & & & & & $\begin{array}{c}0.15 \\
(0.10)\end{array}$ \\
\hline $\mathrm{N}$ & 25 & 25 & 25 & 11 & 20 \\
\hline \multirow[t]{2}{*}{ Adjusted $\mathrm{R}^{2}$} & 0.56 & 0.56 & 0.58 & 0.59 & 0.60 \\
\hline & \multicolumn{4}{|c|}{1994} & \\
\hline USLISTED & $\begin{array}{l}-0.70^{* * *} \\
(0.15)\end{array}$ & $\begin{array}{l}-0.60^{* * * *} \\
(0.13)\end{array}$ & $\begin{array}{l}-0.61 * * * \\
(0.13)\end{array}$ & $\begin{array}{l}-1.67 * * \\
(0.28)\end{array}$ & $\begin{array}{l}-0.43^{* * * *} \\
(0.12)\end{array}$ \\
\hline RESTRICT & & $\begin{array}{l}0.17^{* * * *} \\
(0.07)\end{array}$ & $\begin{array}{l}0.17^{* * *} \\
(0.06)\end{array}$ & $\begin{array}{l}0.18^{* * *} \\
(0.06)\end{array}$ & $\begin{array}{c}0.20^{* *} \\
(0.08)\end{array}$ \\
\hline TRADE & & & $\begin{array}{l}-0.23 \\
(0.27)\end{array}$ & & $\begin{array}{l}-0.03 \\
(0.25)\end{array}$ \\
\hline FDI SALES & & & & $\begin{array}{l}-0.27^{* * *} \\
(0.03)\end{array}$ & \\
\hline REWRISK & & & & & $\begin{array}{l}-0.26^{*} \\
(0.14)\end{array}$ \\
\hline $\mathrm{N}$ & 20 & 20 & 20 & 9 & 13 \\
\hline Adjusted $\mathrm{R}^{2}$ & 0.38 & 0.51 & 0.51 & 0.90 & 0.62 \\
\hline
\end{tabular}

Notes. Dependent variable is BIAS. Constants are included but not reported. USLISTED is the share of the foreign market that is cross-listed on U.S. exchanges. RESTRICT is a measure of foreign ownership restrictions; see text for description. TRADE and FDI SALES are expressed as a share of the foreign country's GNP. REWRISK is the mean over standard deviation of monthly returns calculated over a 15-quarter period. White (1980) standard errors are in parentheses. ${ }^{* * * *},{ }^{*}$, and ${ }^{*}$ indicate significance at the $1 \%, 5 \%$, and $10 \%$ levels, respectively. 
Table 2d

Results: Sample Limited to Countries without Foreign Ownership Restrictions

\begin{tabular}{|c|c|c|c|c|c|}
\hline & (1) & (2) & (3) & (4) & (5) \\
\hline & \multicolumn{4}{|c|}{1997} & \\
\hline USLISTED & $\begin{array}{l}-0.34^{* * *} \\
(0.09)\end{array}$ & & $\begin{array}{l}-0.34^{* * *} \\
(0.09)\end{array}$ & $\begin{array}{l}-0.37^{* * *} \\
(0.09)\end{array}$ & $\begin{array}{l}-0.32^{* * *} \\
(0.08)\end{array}$ \\
\hline TRADE & & & $\begin{array}{c}0.03 \\
(0.09)\end{array}$ & & $\begin{array}{c}0.02 \\
(0.10)\end{array}$ \\
\hline FDI SALES & & & & $\begin{array}{l}-0.17 \\
(0.12)\end{array}$ & \\
\hline REWRISK & & & & & $\begin{array}{l}-0.06 \\
(0.11)\end{array}$ \\
\hline $\mathrm{N}$ & 23 & & 23 & 21 & 23 \\
\hline \multirow[t]{2}{*}{ Adjusted $\mathrm{R}^{2}$} & 0.41 & & 0.38 & 0.46 & 0.35 \\
\hline & \multicolumn{4}{|c|}{1994} & \\
\hline USLISTED & $\begin{array}{l}-0.48^{* * *} \\
(0.09)\end{array}$ & & $\begin{array}{l}-0.48^{* * *} \\
(0.09)\end{array}$ & $\begin{array}{l}-0.45^{* * *} \\
(0.08)\end{array}$ & $\begin{array}{l}-0.47^{* * *} \\
(0.10)\end{array}$ \\
\hline TRADE & & & $\begin{array}{l}-0.01 \\
(0.07)\end{array}$ & & $\begin{array}{c}0.00 \\
(0.08)\end{array}$ \\
\hline FDI SALES & & & & $\begin{array}{l}-0.21 \\
(0.14)\end{array}$ & \\
\hline REWRISK & & & & & $\begin{array}{l}-0.00 \\
(0.18)\end{array}$ \\
\hline $\mathrm{N}$ & 19 & & 19 & 18 & 18 \\
\hline Adjusted $\mathrm{R}^{2}$ & 0.58 & & 0.56 & 0.55 & 0.49 \\
\hline
\end{tabular}

Notes. Dependent variable is BIAS. Constants are included but not reported. USLISTED is the share of the foreign market that is cross-listed on U.S. exchanges. RESTRICT is a measure of foreign ownership restrictions; see text for description. TRADE and FDI SALES are expressed as a share of the foreign country's GNP. REWRISK is the mean over standard deviation of monthly returns calculated over a 15-quarter period. White (1980) standard errors are in parentheses. ${ }^{* * * * *}$, and ${ }^{*}$ indicate significance at the $1 \%, 5 \%$, and $10 \%$ levels, respectively. 


\section{Table 3}

Results: Change in Home Bias

\begin{tabular}{|c|c|c|c|c|}
\hline & $\begin{array}{l}\text { (1) } \\
\text { Full Sample }\end{array}$ & \begin{tabular}{l}
\multicolumn{1}{c}{$(2)$} \\
Countries \\
with \\
Foreign \\
Ownership \\
Restrictions
\end{tabular} & \begin{tabular}{l}
\multicolumn{1}{c}{$(3)$} \\
Countries \\
without \\
Foreign \\
Ownership \\
Restrictions
\end{tabular} & $\begin{array}{l}\text { (4) } \\
\text { Countries } \\
\text { with U.S. } \\
\text { Listings }\end{array}$ \\
\hline & \multicolumn{4}{|c|}{$1994-1997$} \\
\hline BIAS 1994 & $\begin{array}{l}-0.22^{* * *} \\
(0.09)\end{array}$ & $\begin{array}{l}-0.24^{* *} \\
(0.11)\end{array}$ & $\begin{array}{l}-0.26^{* *} \\
(0.08)\end{array}$ & $\begin{array}{l}-0.21^{* *} \\
(0.08)\end{array}$ \\
\hline USLISTED 1994 & $\begin{array}{c}0.11^{*} \\
(0.07)\end{array}$ & $\begin{array}{c}0.01 \\
(0.12)\end{array}$ & $\begin{array}{c}0.17^{* *} \\
(0.09)\end{array}$ & $\begin{array}{c}0.06 \\
(0.06)\end{array}$ \\
\hline$\triangle$ USLISTED & $\begin{array}{l}-0.18^{* *} \\
(0.07)\end{array}$ & $\begin{array}{l}-0.27^{* * *} \\
(0.07)\end{array}$ & $\begin{array}{l}-0.02 \\
(0.09)\end{array}$ & $\begin{array}{l}-0.26^{* * *} \\
(0.07)\end{array}$ \\
\hline $\mathrm{N}$ & 44 & 24 & 20 & 35 \\
\hline Adjusted $\mathrm{R}^{2}$ & 0.41 & 0.19 & 0.61 & 0.50 \\
\hline
\end{tabular}

Notes. Dependent variable is the change in BIAS from 1994 to 1997 . The change in USLISTED is also from 1994 to 1997 . See notes to Table 2 a for more complete descriptions. Constants are included but not reported. White (1980) standard errors are in parentheses. ${ }^{* * * * *}$, and ${ }^{*}$ indicate significance at the $1 \%, 5 \%$, and $10 \%$ levels, respectively. 


\section{Table 4}

Results: Transaction Costs

\begin{tabular}{|c|c|c|c|c|c|c|c|c|}
\hline \multirow[b]{2}{*}{ COSTS } & \multicolumn{2}{|c|}{$\begin{array}{l}(1) \\
\text { Full Sample }\end{array}$} & \multicolumn{2}{|c|}{$\begin{array}{l}\text { (2) } \\
\text { Countries with Foreign } \\
\text { Ownership Restrictions }\end{array}$} & \multicolumn{2}{|c|}{$\begin{array}{c}(3) \\
\text { Countries without Foreign } \\
\text { Ownership Restrictions }\end{array}$} & \multicolumn{2}{|c|}{$\begin{array}{c}\text { (4) } \\
\text { Countries with U.S. Listings }\end{array}$} \\
\hline & $\begin{array}{l}-0.03 \\
(0.11)\end{array}$ & $\begin{array}{c}0.13 \\
(0.11)\end{array}$ & $\begin{array}{l}-0.03 \\
(0.15)\end{array}$ & $\begin{array}{l}-0.14 \\
(0.25)\end{array}$ & $\begin{array}{l}-0.48^{*} \\
(0.25)\end{array}$ & $\begin{array}{l}-0.16 \\
(0.17)\end{array}$ & $\begin{array}{l}-0.06 \\
(0.11)\end{array}$ & $\begin{array}{c}0.15 \\
(0.13)\end{array}$ \\
\hline USLISTED & & $\begin{array}{l}-1.01^{* * *} \\
(0.25)\end{array}$ & & $\begin{array}{l}-0.30 \\
(0.81)\end{array}$ & & $\begin{array}{l}-0.74^{* * *} \\
(0.22)\end{array}$ & & $\begin{array}{l}-1.11^{* * *} \\
(0.27)\end{array}$ \\
\hline $\begin{array}{l}(1-\text { COSTS }) \\
* \\
\text { USLISTED }\end{array}$ & & $\begin{array}{l}1.69^{* *} \\
(0.70)\end{array}$ & & $\begin{array}{l}-0.66 \\
(2.48)\end{array}$ & & $\begin{array}{c}1.07 \\
(0.70)\end{array}$ & & $\begin{array}{l}1.82^{* *} \\
(0.76)\end{array}$ \\
\hline $\mathrm{N}$ & 41 & 41 & 19 & 19 & 22 & 22 & 35 & 35 \\
\hline Adjusted $\mathrm{R}^{2}$ & 0.0 & 0.54 & 0.0 & 0.46 & 0.16 & 0.58 & 0.0 & 0.53 \\
\hline
\end{tabular}

Notes. Data are for 1997. See notes to Table 2a. COSTS are relative transaction costs, calculated by normalizing the Elkins-

McSherry Co. data by the highest cost country (Korea). Constants are included but not reported. White (1980) standard errors are in parentheses. ${ }^{* * * * *}$, and ${ }^{*}$ indicate significance at the $1 \%, 5 \%$, and $10 \%$ levels, respectively. 


\section{Table 5}

Results: Accounting Standards and Rule of Law

\begin{tabular}{|c|c|c|c|c|}
\hline & (1) & (2) & (3) & (4) \\
\hline & \multicolumn{4}{|c|}{1994} \\
\hline ACCT & $\begin{array}{l}-0.16 \\
(0.15)\end{array}$ & & $\begin{array}{c}0.07 \\
(0.13)\end{array}$ & $\begin{array}{l}-0.38 \\
(0.33)\end{array}$ \\
\hline ROL & & $\begin{array}{l}-0.02^{* * *} \\
(0.01)\end{array}$ & $\begin{array}{l}-0.01 \\
(0.01)\end{array}$ & $\begin{array}{c}0.04^{*} \\
(0.03)\end{array}$ \\
\hline USLISTED & & & $\begin{array}{l}-0.52^{* * *} \\
(0.09)\end{array}$ & $\begin{array}{l}-1.56^{* * *} \\
(0.34)\end{array}$ \\
\hline $\mathrm{ACCT} * \mathrm{ROL}$ & & & & $\begin{array}{l}-0.08^{*} \\
(0.05)\end{array}$ \\
\hline ACCT * USLISTED & & & & $\begin{array}{l}2.38^{* * *} \\
(0.91)\end{array}$ \\
\hline ROL * USLISTED & & & & $\begin{array}{l}-0.55 \\
(0.46)\end{array}$ \\
\hline $\mathrm{N}$ & 37 & 39 & 37 & 37 \\
\hline Adjusted $\mathrm{R}^{2}$ & 0.0 & 0.13 & 0.51 & 0.52 \\
\hline
\end{tabular}

Notes. ACCT is 1990 accounting standards as compiled by the Center for International Financial Analysis and Research. ROL is 1982 to 1995 rule of law as compiled by the International Country Risk rating agency. Both ACCT and ROL are taken from La Porta et al (1998). Dependent variable is the level of BIAS in 1994. Constants are included but not reported. White (1980) standard errors are in parentheses. ${ }^{* * * * *}$, and ${ }^{*}$ indicate significance at the $1 \%, 5 \%$, and $10 \%$ levels, respectively. 
Figure 1: Share of Foreign Equities in the U.S. Stock Portfolio

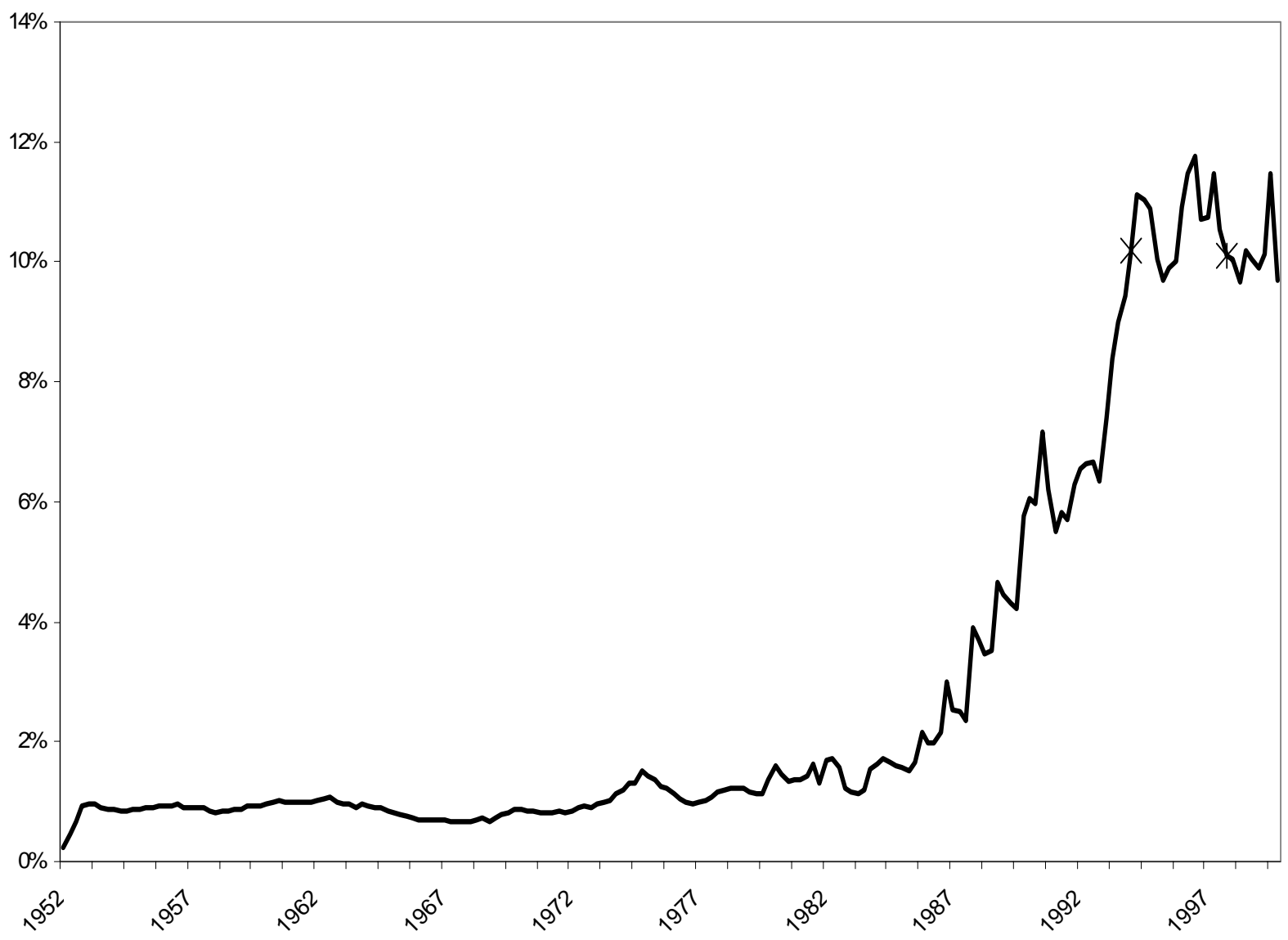

Notes: The two data points marked with asterisks, March 1994 and December 1997, are the only data points for which there are actual data on U.S. holdings of foreign securities. U.S. stock portfolio is U.S. market capitalization plus U.S. holdings of foreign stocks less foreign holdings of U.S. stocks.

Source: Flow of Funds Accounts of the United States

(www.federalreserve.gov/releases/z1/current/data.htm) 
Figure 2: Country Bias in U.S. Equity Holdings

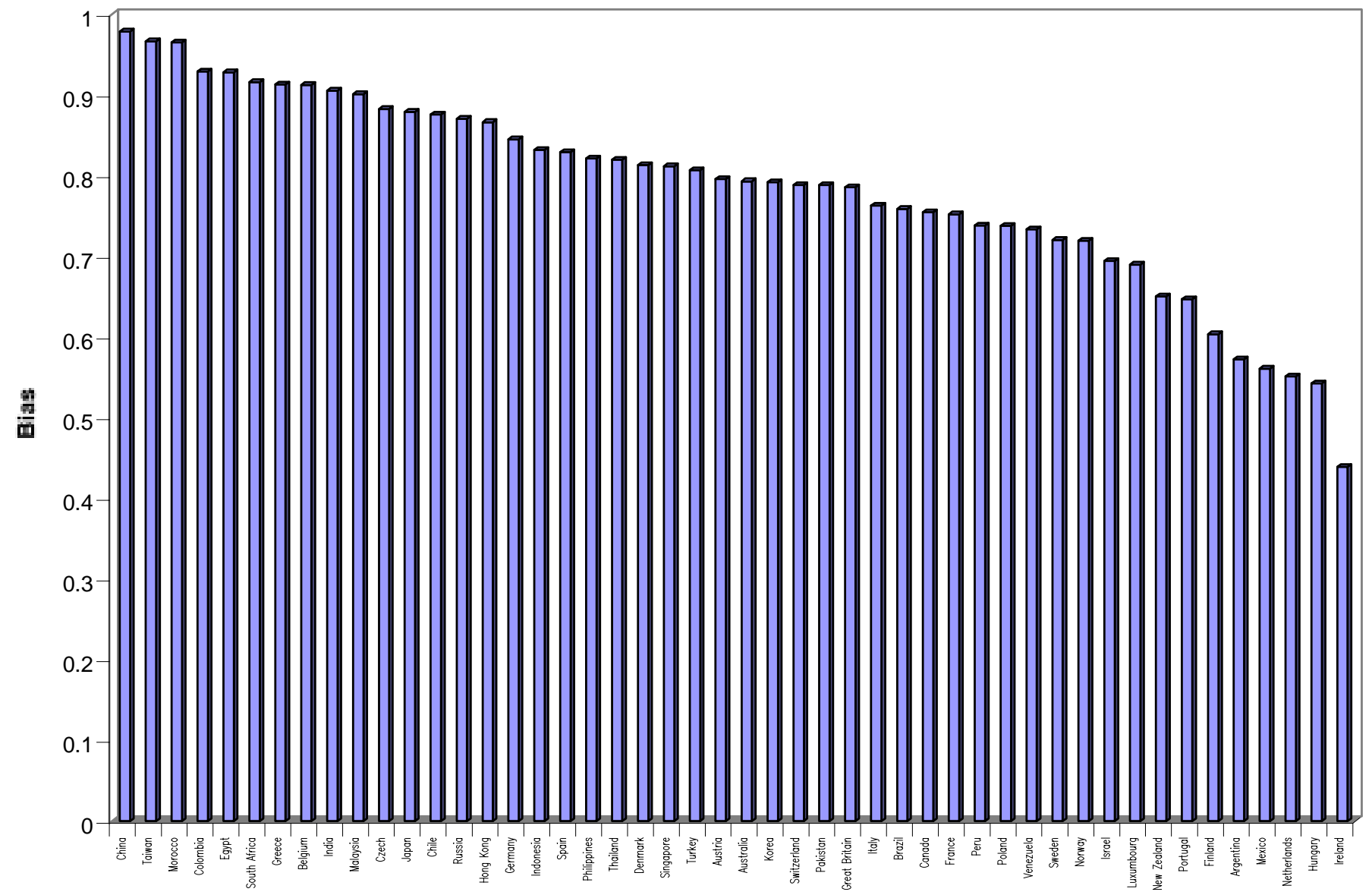

Note: Country Bias $=1$ - Actual U.S. Holdings $\div$ ICAPM Benchmark. See Table 1 . 
Figure 3: Share of Foreign Market Listed on U.S. Exchanges, 1997

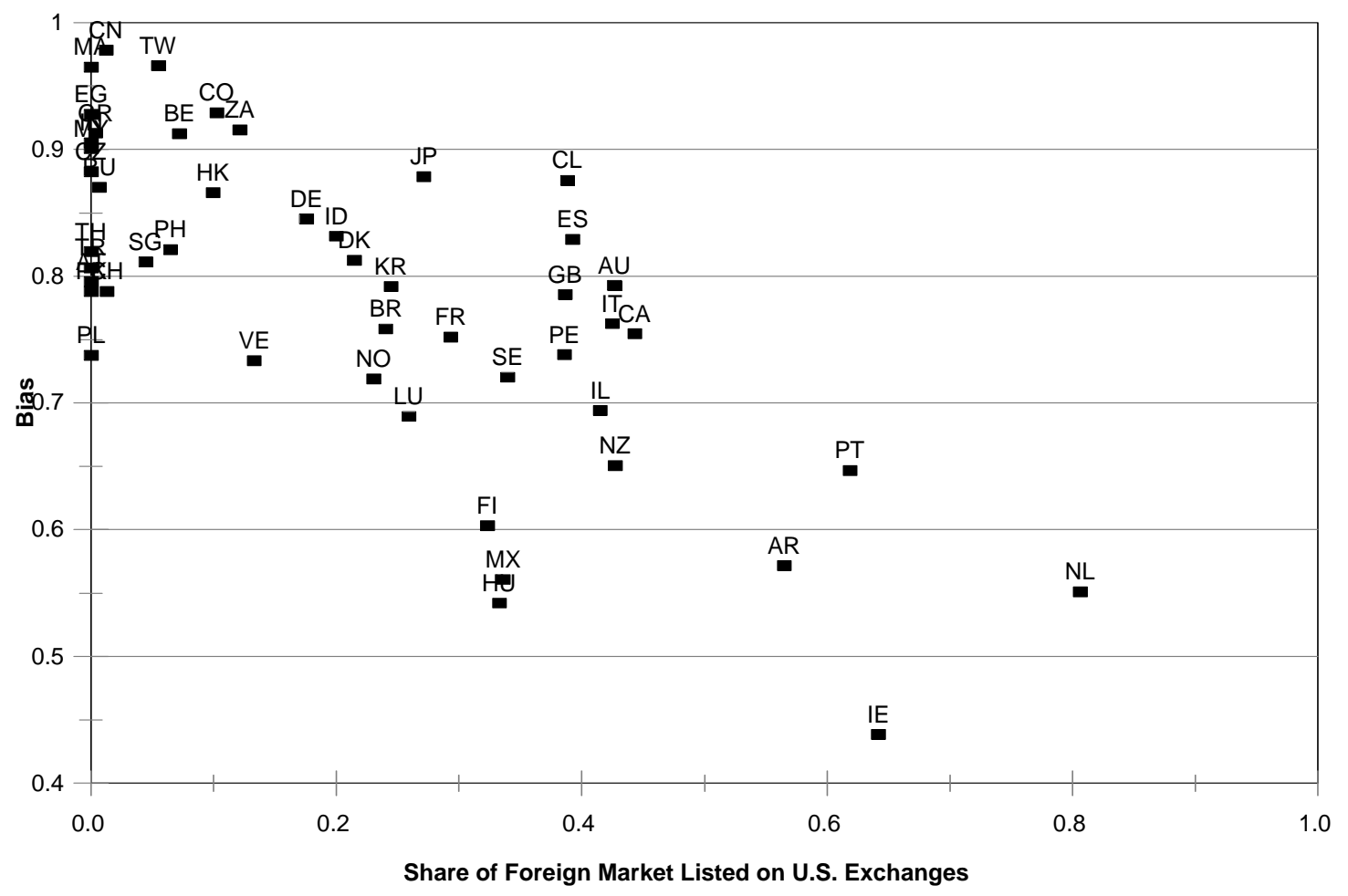


Figure 4: Trade, 1997

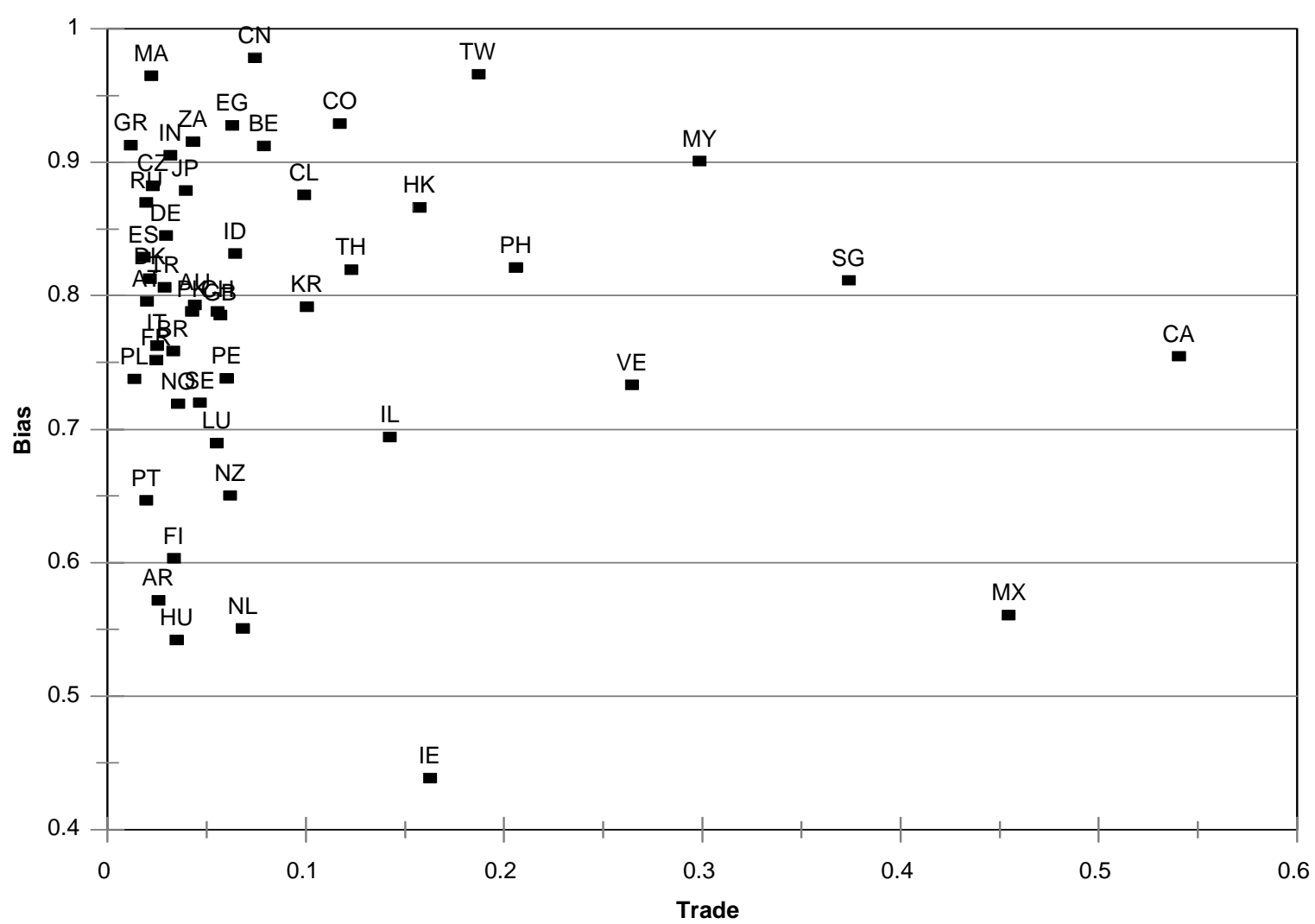

Note: TRADE for country $i$ is country $i$ 's total trade with the United States as a proportion of country $i$ 's GNP. 
Figure 5: Sales by FDI Affiliates in the U.S., 1997

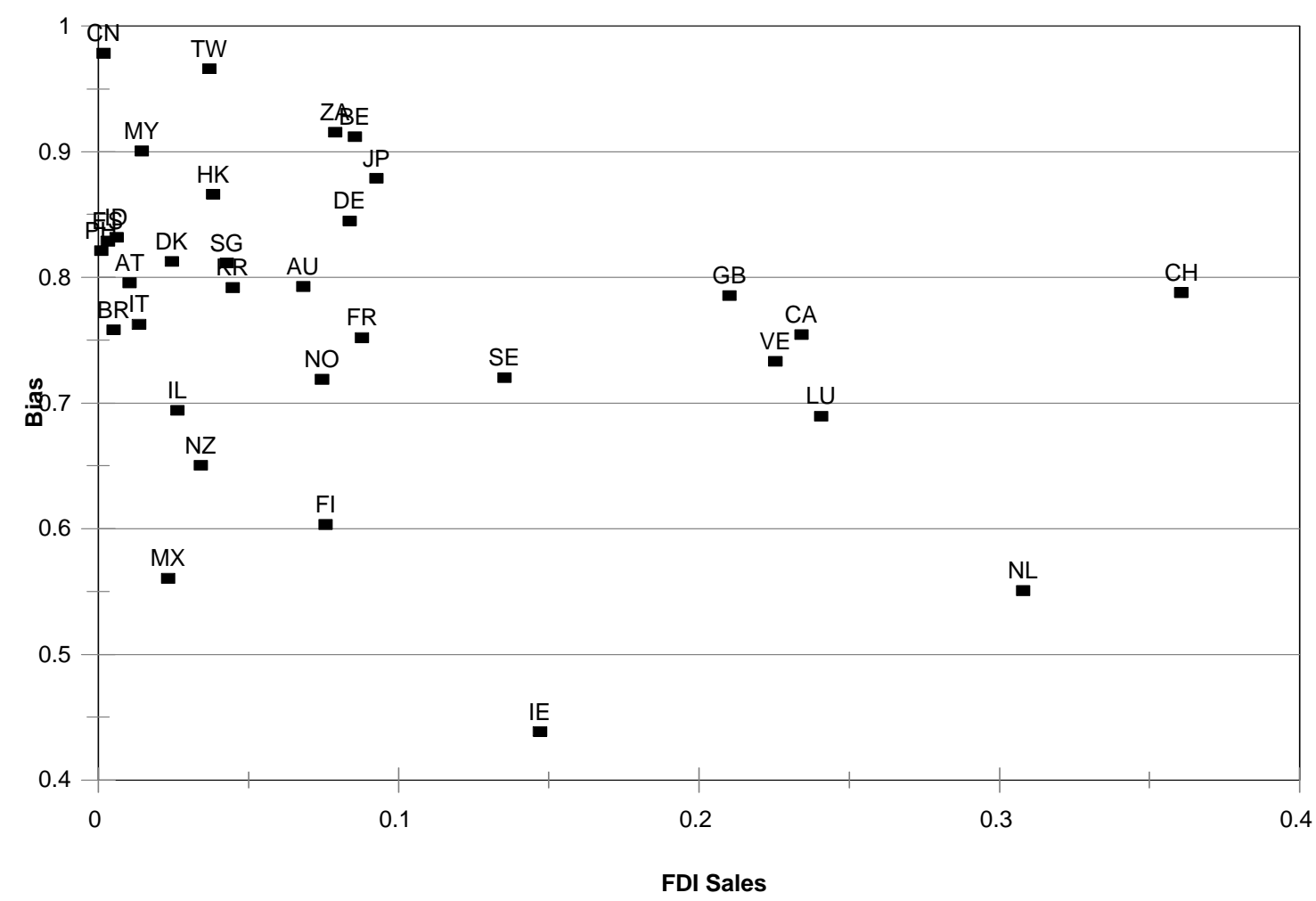

Note: FDI SALES for country $i$ is sales by country $i$ 's affiliates in the United States as a proportion of country $i$ 's GNP. 
Figure 6: Foreign Ownership Restrictions, 1997

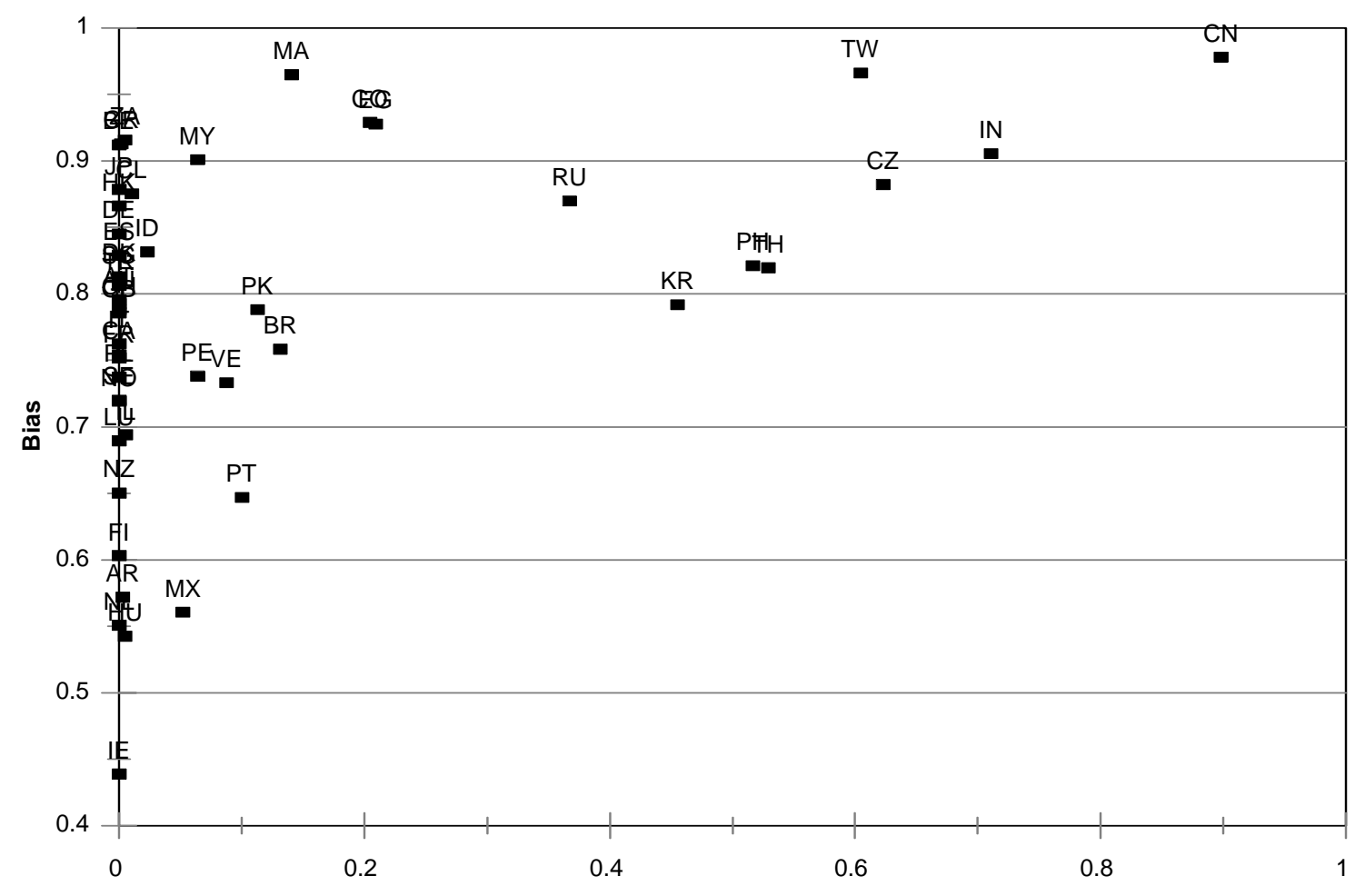

Foreign Ownership Restrictions 
Figure 7: Reward-to-Risk Ratio, 1997

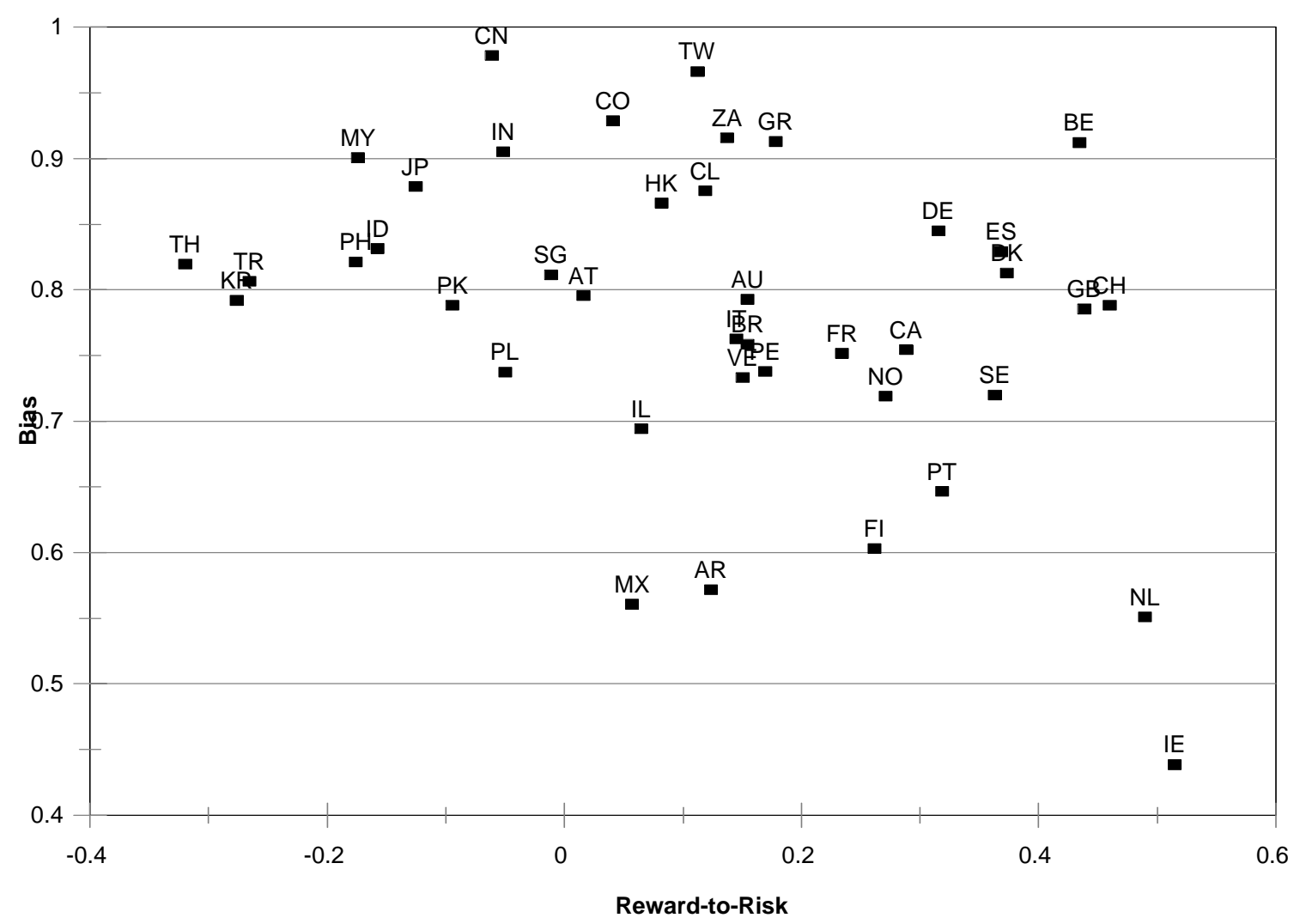


Figure 8: Relative Transaction Costs, 1997

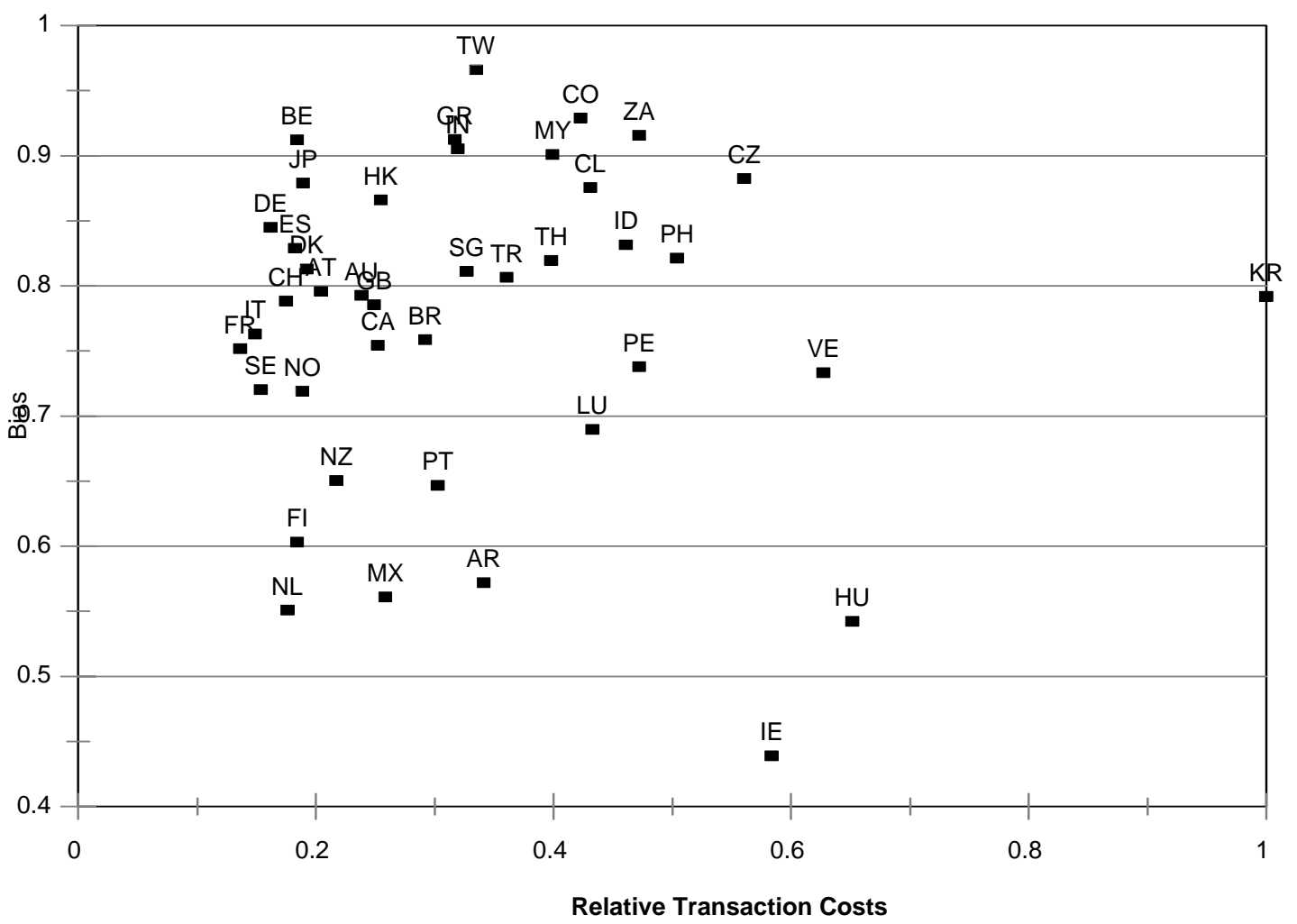

